\title{
Chapter 5 \\ Inorganic Soil Constituents Sensitive to Varying Redox Conditions
}

\begin{abstract}
Inorganic soil constituents sensitive to varying redox conditions, such as hydrated iron oxide, vivianite, siderite, iron (II) sulfides, and jarosite, are analyzed using optical and electron microscopes, energy dispersive X-ray spectroscopy (EDX), and X-ray diffraction (XRD). Many of these minerals are sourced from paddy field soils, which undergo reducing and oxidizing conditions in the plow layer every year. Iron mottles formed at the soil redox interface in the presence of reducing and oxidizing conditions provide significant visual evidence of varying redox conditions in soil. Polished sections were used to examine the elemental distributions and morphological properties of the mottles. One type of iron mottles is formed around rice roots by oxygen diffusion from the roots. They are cylindrical in form and include soil matrix minerals. Other type of iron mottles is formed on the surfaces of irregular or vesicular pores by oxygen diffusion through soil pores after drainage. These mottles contain few soil matrix minerals. In association with iron, the distribution of phosphate is strongly affected by changes in redox conditions in paddy field soils with low active $\mathrm{Al}$ content.
\end{abstract}

\subsection{Introduction}

Oxidizing conditions are common in surface soils in an oxygen-containing atmosphere. Under oxidizing conditions, the major factors affecting dissolution and precipitation reactions in soil are the $\mathrm{pH}$, temperature, and elemental composition of the soil. For example, Ca carbonate dissolves in acid soils, whereas it precipitates in alkaline soils. However, under submergence or high ground water level, reducing conditions develop in soil associated with microbial activity. For example, the solubility of iron is very low in neutral and alkaline soils, whereas a part of iron dissolves under reducing conditions. Thus, changes in redox conditions affect the chemical forms of elements, including redox-sensitive elements and related elements (Ponnamperuma 1972). The morphological properties of soil profiles are also affected by these redox reactions (Vepraskas and Craft 2016).

Reduced soils are typically characterized by the reduction of iron, as included in the diagnostic criteria for redoximorphic features in the United States Department of 
Agriculture - Soil Taxonomy (USDA-ST) (Soil Survey Staff 1999) and gleyic properties in the World Reference Base for Soil Resources (WRB) (IUSS Working Group WRB 2015). Iron is one of the major elements in soil, and it strongly affects soil color and mottle formation.

In relation to redox reactions, the soil $\mathrm{pH}$ also changes. For example, $\mathrm{pH}$ increases with reduction of hydrated iron (III) oxide, and decreases with oxidation of ferrous iron (iron(II)). A pH-pE diagram can be used as a method to describe the chemical stability of minerals under varying redox conditions in soil, and is recommended for further study (Stumm and Morgan 1996; Kyuma 2004).

\subsubsection{Alternating Oxidized and Reducing Conditions in Paddy Field Soils}

Paddy field soils are an example of soil with varying redox conditions. The total paddy-field land area comprises irrigated, rain-fed lowland, and rain-fed upland paddy fields covering 93, 52, and 15 million ha (Global Rice Science Partnership 2013), respectively. More than $90 \%$ of the paddy fields in the world are distributed in Asia. Elsewhere, paddy fields are distributed in temperate, subtropical, and tropical areas where enough water is available. The rain-fed lowland paddy field area includes that covered by deep-water rice. Although significant areas of irrigated paddy fields are also grown in rotation with a range of other crops, lowland paddy field soils experience relatively reducing conditions when rice is grown under submergence. Merits of submergence are (i) high rice yield, (ii) weed control, (iii) an increase in phosphate availability under reducing conditions, (iv) supply of micronutrients as solutes in irrigation water, and (v) high $\mathrm{N}$-fixation ability compared to ordinary uplands (Kyuma 2004). This chapter focuses on paddy field soils, and lowland soils with high ground water level in relation to their varying redox conditions.

Reducing conditions are caused by microbial activity. Three typical requirements for the development of reducing conditions are (i) submergence of soil in water to restrict oxygen diffusion, (ii) appropriate temperature for microbial activity, and (iii) carbon source for microbes. Oxidizing forms of $\mathrm{C}, \mathrm{N}, \mathrm{Mn}, \mathrm{Fe}$, and $\mathrm{S}$ are also important, and nearly-neutral soil $\mathrm{pH}$ is preferable for microbial activity. In contrast, when reduced soil is exposed to air due to drainage or ground water level fall, the soil becomes oxidized.

Major elements affected by varying redox conditions in soil are $\mathrm{C}, \mathrm{N}, \mathrm{Mn}, \mathrm{Fe}$, and $\mathrm{S}$. The behavior of contaminant elements in soil, such as $\mathrm{Cd}, \mathrm{Cu}$, and $\mathrm{As}$, is also affected by varying redox conditions. Sulfide precipitation of $\mathrm{Cd}$ and some other heavy metals is possible under reducing conditions. The oxidation numbers of $\mathrm{Cu}$ and As change with redox potential.

Figure 5.1 illustrates changes in the color of soil and rice roots as a result of redox reactions. An Ap horizon (plow layer) soil (Udifluvent, according to the USDA-ST), which was sampled from a paddy field, was used. The oxalate-extractable $\mathrm{Fe}\left(\mathrm{Fe}_{\mathrm{o}}\right)$, 


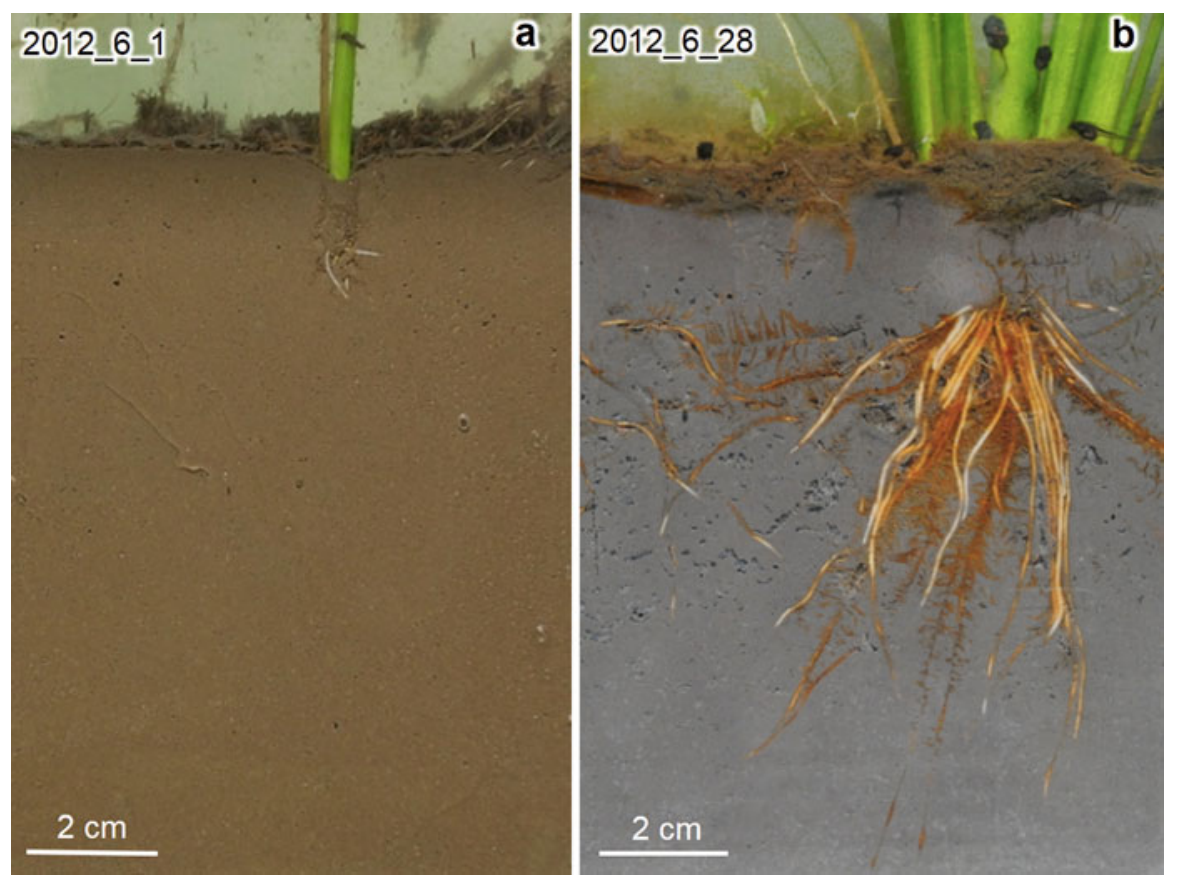

Fig. 5.1 Changes in soil color with submergence. (a) 4 days after submergence, mixing, and rice transplanting (June 1, 2012), (b) 31 days after submergence (June 28, 2012) in a glass vessel

oxalate-extractable $\mathrm{Al}\left(\mathrm{Al}_{\mathrm{o}}\right)$, total organic carbon (TOC), and cation exchange capacity (CEC) values are $8.6,1.2,23.0 \mathrm{~g} \mathrm{~kg}^{-1}$, and $23.6 \mathrm{cmol}_{\mathrm{c}} \mathrm{kg}^{-1}$, respectively (Kusunoki et al. 2015). The major iron mineral in the paddy field soil appears to be poorly crystalline ferrihydrite (Childs et al. 1991; Hansel et al. 2001; Fu et al. 2016). These chemical properties are common to the plow layer of lowland paddy field soils in Japan. Figure 5.1a shows the original brown soil color, and the roots of transplanted rice are white and short.

At 31 days after transplanting, the soil color turned grayish due to reduction of ferrihydrite to ferrous iron (Fig. 5.1b). The largest portion of the ferrous iron appears to remain as exchangeable $\mathrm{Fe}^{2+}$ in the soil. At the boundary between the water and the reduced soil, brownish soil, which is called an oxidative layer, remains due to diffusion of oxygen from the air. There are very small dark-colored areas between the oxidative layer and the underlying reduced soil. This dark color resembles noncrystalline ferrous sulfide, as shown in Sect. 5.5.1.

The number of rice roots increased in Fig. 5.1b, and the roots are whitish and brown in color. The rice roots can be classified into three groups based on their diameter: (i) thick $(0.5-1 \mathrm{~mm})$, (ii) intermediate (approximately $0.3 \mathrm{~mm}$ ), and (iii) thin $(0.1-0.15 \mathrm{~mm})$. The intermediate and thin roots develop around the thick roots. The very young roots are whitish. Associated with the formation of aerenchyma and lysigenous intercellular space (Kawai et al. 1998), the color of both the thin and thick 
roots turns brown. This brown color is due to diffusion and concentration of ferrous iron, followed by oxidation of the ferrous iron by oxygen diffusion through the rice roots (Ando et al. 1983; Sadana and Claassen 1996), and precipitation of ferric iron (iron(III)), resulting in the formation of iron plaque (Kahn et al. 2016). Thus, the main redox interface sites in paddy field soil are located between the oxidative soil layer and underlying reduced soil, and between the rice roots and reduced soil. The other redox interface in paddy field soil is between the reduced soil and the underlying oxidative subsoil. Reducing conditions can be found most clearly using the dipyridyl test, which detects the presence of $\mathrm{Fe}^{2+}$.

The color change of a soil profile with an increase in reducing conditions may depend on soil properties. Since the color of the Ap horizon in Andisols is dark, where the dark color is due to high content of highly-humified humus, the color change with an increase in reducing conditions, such as in Fig. 5.1, may be masked even when $\mathrm{Fe}^{2+}$ is detected with the dipyridyl test. Fading of the light brown color of goethite aggregates in an incubated soil under submergence is slow, possibly due to the high stability of goethite crystals.

\subsubsection{Redox Reactions in Soil}

Important redox reactions in the plow layer of a paddy field soil under submergence are shown schematically in Fig. 5.2, where the background figure is similar to Fig. 5.1b. With a decrease in the soil Eh value (The potential that is generated between an oxidation or reduction half-reaction and the standard hydrogen electrode $(0.0 \mathrm{~V}$ at $\mathrm{pH}=0)$, (Glossary of Soil Science Committee 2008)), several or more reactions proceed in order of decreasing $\mathrm{Eh}^{0}(\mathrm{pH} 7)$, as shown in Fig. 5.2c. The reason for using $\mathrm{Eh}^{0}(\mathrm{pH} 7)$ in Fig. 5.2c is that the $\mathrm{pH}\left(\mathrm{H}_{2} \mathrm{O}\right)$ value of the paddy field Ap horizon soil after reduction is around 7, whereas the $\mathrm{pH}$ of the same air-dried soil

Fig. 5.2 Simplified redox reactions in the plow layer soil of a paddy field under submergence. (a) irrigation water, (b) oxidizing layer, (c) reducing layer). "Fe(III)" denotes $\mathrm{Fe}(\mathrm{OH})_{3}$ (amorphous). For more information, see Stumm and Morgan (1996), Kyuma (2004)

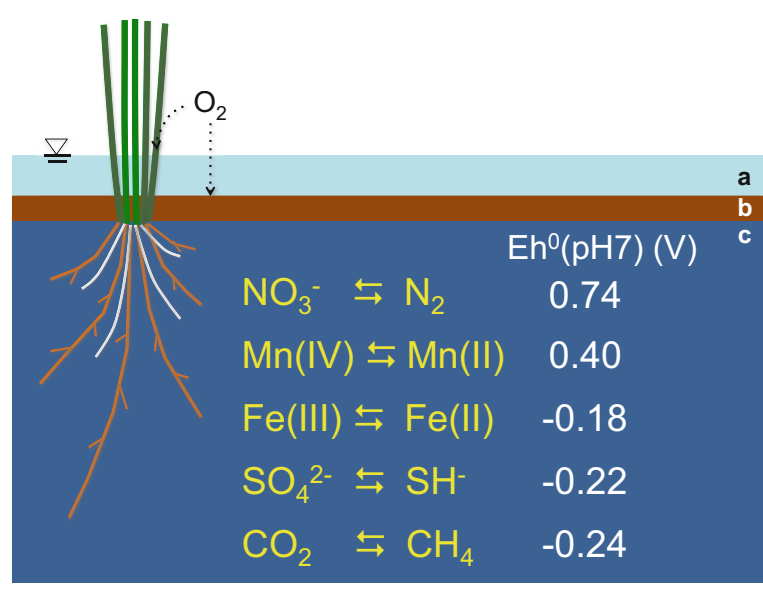


typically ranges between 5 and 6 . The $\mathrm{pH}$ change between oxidized and reduced soils is exemplified by the reaction $\mathrm{Fe}(\mathrm{OH})_{3}$ (amorphous) $\rightleftarrows \mathrm{Fe}^{2+}$ (negatively charged site $)+3 \mathrm{OH}^{-}+\mathrm{e}^{-}$.

The Eh value of irrigation water (Fig. 5.2a) is high due to the addition of $\mathrm{O}_{2}$ from the air. In the oxidizing layer (Fig. 5.2b), the Eh value decreases steeply to around $-0.2 \mathrm{~V}$ at the boundary between the oxidizing layer (Fig. 5.2b) and the reducing layer (Fig. 5.2c), estimated from the presence of dark-colored noncrystalline iron sulfide (Fig. 5.1b). The lowest Eh value in the reducing layer is typically $-0.2 \sim-0.3 \mathrm{~V}$. The thickness of the oxidizing layer ranges between around 0.5 and $5 \mathrm{~cm}$.

Oxygen diffuses from the air to the rice roots through the aerenchyma, whereas the bulk soil is reduced under submergence. A redox interface is also formed between the aerenchyma and the bulk soil. At this redox interface, there are three or more cell layers, which are the epidermis, exodermis, and sclerenchyma (one or more layers), forming the outer part of a rice root (Kondo et al. 2000). With aging, the epidermis layer is sloughed off first, whereas the exodermis and/or sclerenchyma remain along with deposition of hydrated iron oxide and other materials.

Methane can be formed by reduction of $\mathrm{CO}_{2}$, which may form through oxidation of organic matter by microbes. Carbon dioxide and $\mathrm{CH}_{4}$ gases can form vesicular or irregular pores in the submerged and reduced soil. Although the vapor phase ratio of the puddled plow layer soil is only $1-3 \%$, it increases to $9-12 \%$ at around 40 days after puddling and submergence, possibly due to formation of these gases (Saito and Kawaguchi 1971a, b). One can easily notice the existence of gases from bubbling when he steps in the submerged paddy field 1 or 2 months after submergence. Methane formed in the reduced soil can be released to the air through the aerenchyma of the rice plants (Yagi 1997).

Iron is the most abundant member of the redox-sensitive elements in soil. Ferrous iron reacts with phosphate, carbonate, and sulfide to produce vivianite (see Sect. 5.3), siderite (see Sect. 5.4), and iron sulfide (see Sects. 5.5.1 and 5.5.2), respectively.

The occurrence of oxidizing conditions in the reduced paddy field soil depends on the management of irrigation water, as shown in Fig. 5.4. Oxidizing conditions after drainage can be detected most clearly from a lack of dipyridyl reaction and the presence of iron mottles (see Sect. 5.2).

Since the manganese content in soil is typically one-fifth or less of that of iron, it has limited effects on the morphological properties of Ap horizon soil, although faint and soft manganese concretions may be found in the paddy field subsoil. Nitrate is easily reduced to $\mathrm{N}_{2}$ by denitrifiers, which affects the efficiency of $\mathrm{N}$ fertilizers, but does not affect the morphological properties of the Ap horizon soil. 


\subsubsection{Water Management and Characteristics of a Paddy Field Soil Profile}

The area percentage of irrigated paddy fields is approximately $60 \%$ of the total paddy-field area in the world (Global Rice Science Partnership 2013). Figure 5.3 shows an example of seasonal changes in an irrigated paddy field in Miyagi Prefecture, Japan. In spring, farmers till the drained paddy field (Fig. 5.3a) and apply basal fertilizers (Fig. 5.3b). During this season, paddy fields are partially dried. After introducing water, puddling, and transplanting in late spring, rice plants are grown under submergence (Fig. 5.3c) until the maximum tillering stage in early summer. Following midseason drainage for 2 weeks, the paddy field is irrigated intermittently or submerged again (Fig. 5.3d) until the end of August. Then, irrigation is stopped and the paddy fields are dried for harvest (Fig. 5.3e).

The Eh value in the plow layer soil of paddy fields responds to the paddy field water management. Changes in Eh value were monitored using a platinum electrode connected to a reference electrode and a voltmeter. Figure 5.4 shows examples of Eh change with paddy field water management. Three water management schemes were carried out: midseason drainage and intermittent irrigation (Fig. 5.4a), midseason drainage and submergence (Fig. 5.4b), and continuous submergence (Fig. 5.4c).

At about 50 days after transplanting and submergence, the Eh values ranged around -0.1 to $-0.2 \mathrm{~V}$, suggesting that all three of the plow layer soils were nearly fully reduced due to continuous submergence. The Eh values of plots (a) and (b) increased with midseason drainage. Subsequently, the Eh value of plot (a) tended to be higher than those of the other plots due to intermittent irrigation, whereas the Eh value of plot (b) decreased to the same level as that of plot (c), which was continuously submerged. One hundred and ten days after transplanting, all the
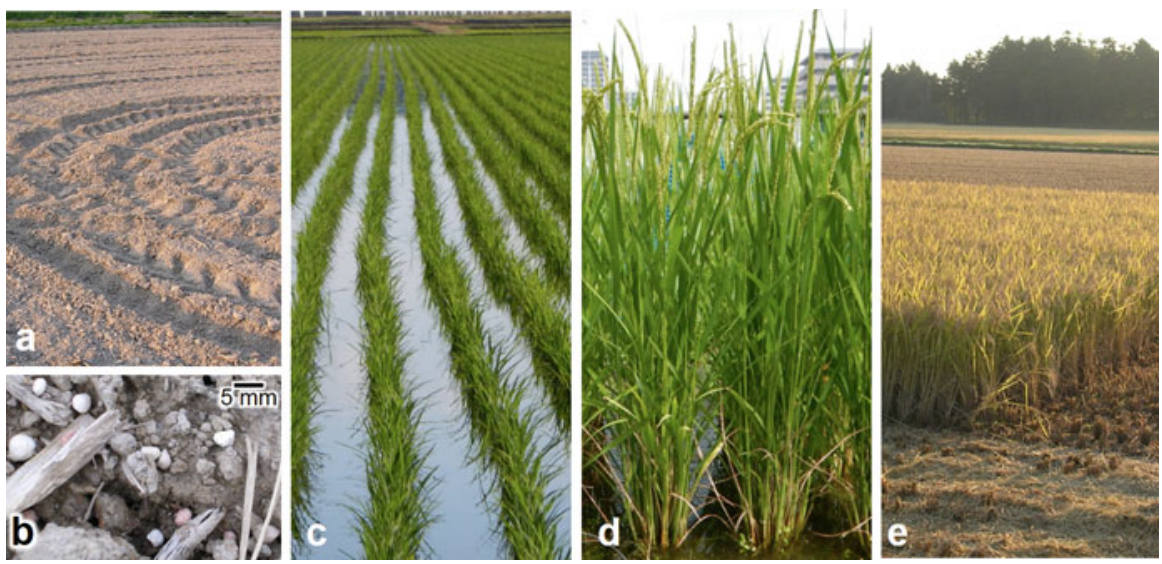

Fig. 5.3 Seasonal changes in a paddy field. (a) After spring tillage and basal fertilizer application, (b) close-up view of applied fertilizers, (c) initial growth with submergence, (d) heading stage, (e) rice plant harvest time 


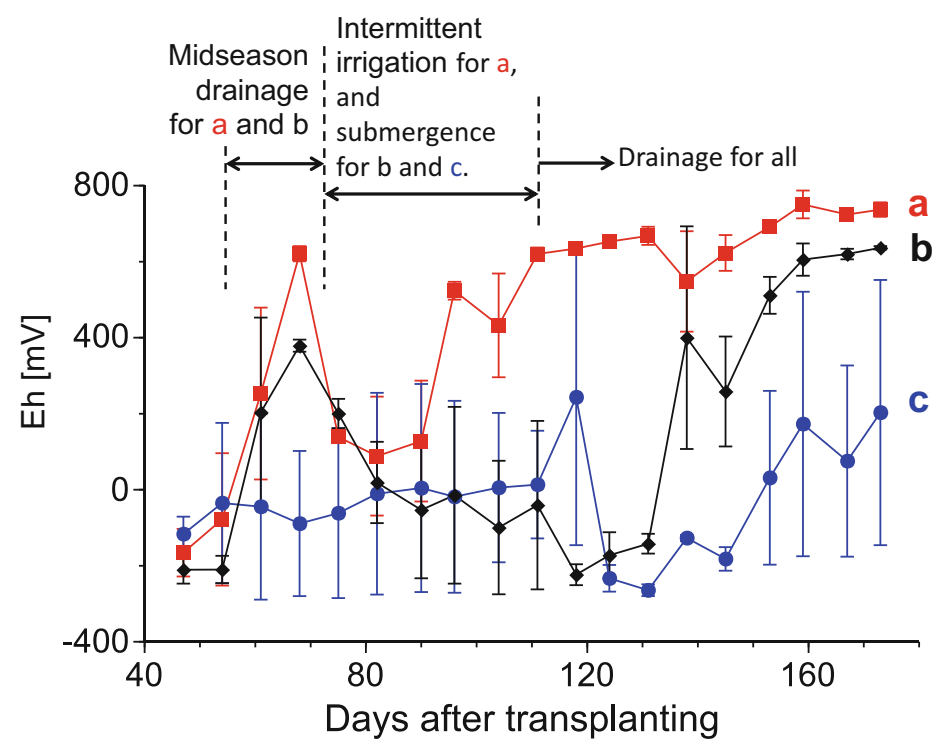

Fig. 5.4 Changes in soil redox potential values (Eh) with different water management schemes. (a) Midseason drainage and intermittent irrigation (MI), (b) midseason drainage and submergence (MS), (c) continuous submergence (CS). The error bars show the absolute deviation from the mean $(\mathrm{n}=2)$

plots were drained, as is usual in the water management practice of irrigated paddy fields. At the start of drainage, the Eh value of plot (a) was already higher than those of the other plots due to its treatment by midseason drainage followed by intermittent irrigation. The Eh value of plot (c) was the lowest, even after drainage started, due to continuous submergence, which may have delayed drainage compared to plot (b).

As a result of redox reactions caused by the water management schemes, the paddy field plow layer soils show periodic chemical changes every year. Directly under the plow layer soil, the plow pan, also common to paddy field soils, is formed. The plow pan is $5-10 \mathrm{~cm}$ thick, hard, and sometimes has weakly developed platy structure with hydrated iron oxide coating or mottles. In contrast, the properties of the lower horizon soils under the plow pan are mainly related to topography and ground water level, as well as related to redox reactions. Paddy fields can be divided into two types: well-drained and poorly drained (Kyuma et al. 1988; Wada and Neue 1988). Intermediate types also exist.

Well-drained paddy fields are distributed in relatively well-drained areas, such as uplands or natural levees in lowland areas. The lower horizon soils underlain by the plow pan are unsaturated with water and oxidative at least during the time when the paddy field is not submerged. As the plow layer soil is reduced under submergence with water permeability of approximately $2-3 \mathrm{~cm} \mathrm{~d}^{-1}, \mathrm{Mn}^{2+}$ and $\mathrm{Fe}^{2+}$ are gradually transported to the subsoil, oxidized, and precipitated, forming Mn- and Fe-mottled and enriched layers. The Fe-enriched layer is more distinct and occurs shallower 


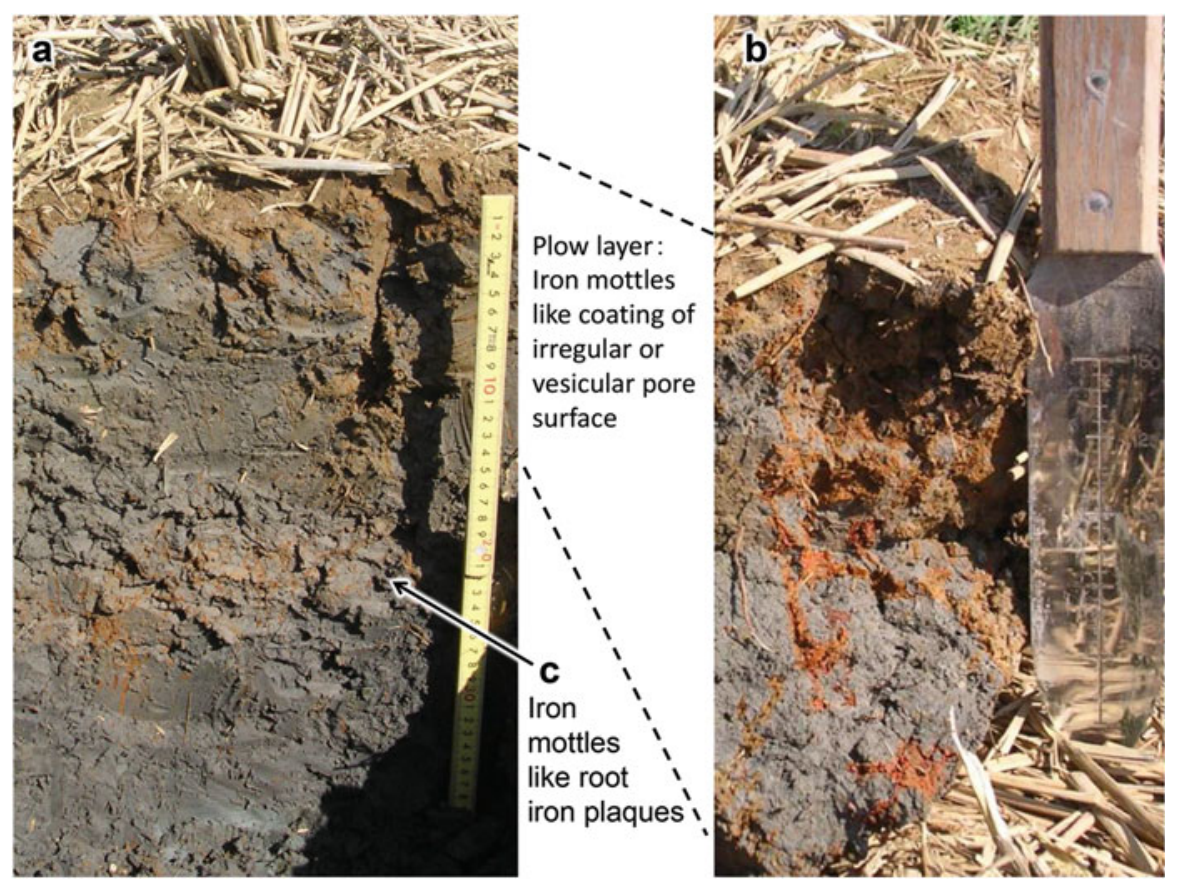

Fig. 5.5 Poorly drained paddy field soil. (a) Two major types of iron mottles found in paddy field soils. (b) iron mottles resembling a coating of irregular or vesicular pore surfaces, (c) cylindrical iron mottles resembling root iron plaque

than the Mn-enriched layer (Wada and Neue 1988; Kyuma 2004), reflecting the difference in $\mathrm{Eh}^{0}(\mathrm{pH}$ 7) values of the redox reactions related to these elements (Fig. 5.2).

Poorly drained paddy fields are distributed in marshlands or other areas with high ground water levels. The lower horizon soil directly under the plow layer is saturated with water and reduced, even after irrigation is stopped, due to high ground water level and low water permeability (Fig. 5.5a). The subsoil is bluish gray in color with faint enrichment of Mn and Fe (Kyuma 2004).

\subsection{Hydrated Iron Oxide}

Hydrated iron oxides are the most abundant redox-sensitive inorganic constituents in soil. Here pick up hydrated iron oxide of paddy field soils including iron mottles. The exemplified iron mottles correspond to redox concentrations described by Vepraskas (1992) and Hurt et al. (1996). Hydrated iron oxides here may range from noncrystalline hydrated iron oxide to ferrihydrite and poorly crystalline iron 
oxyhydroxides. Under oxidizing conditions, the $\mathrm{Fe}_{\mathrm{o}} /$ dithionite-extractable iron $\left(\mathrm{Fe}_{\mathrm{d}}\right)$ values of paddy field plow layer soils are higher than 0.3 , suggesting that the major form of iron is poorly crystalline ferrihydrite due to yearly repetition of reduction and oxidation, i.e., dissolution and precipitation (Childs et al. 1991). Although lepidocrocite was identified in the iron mottles (Kojima 1971), lepidocrocite is partly soluble in acid oxalate solution (dark) (Schwertmann 1973; Fonseca and da Silva 1998). A significant form of ferrous iron is exchangeable or acetate-extractable $\mathrm{Fe}^{2+}$ (Kyuma 2004), and other forms of ferrous iron may include vivianite, siderite, and noncrystalline ferrous sulfide.

Figure 5.5a shows a profile of a poorly drained paddy field soil. The plow layer soil is gray in color, suggesting that the bulk soil is still under reducing conditions although irrigation had been stopped more than one month before, and the rice harvest was finished. As the texture of this soil is fine (Togami et al. 2017), with the major clay mineral being montmorillonite (Fig. 3.8), the soil is poorly drained. This soil profile contains two major types of iron mottles. The first type is brown-colored iron mottles, which resemble a coating of irregular or vesicular pore surfaces, as shown in Fig. 5.5b. Since the pore surface coating-like mottles are found in the plow layer soil, they were formed after puddling in the spring of that year. During the next rice cultivation, the mottles will be reduced and dissolved again. The second type is cylindrical iron mottles, which resemble root iron plaque. Since the layer rich in these mottles is deeper than $15 \mathrm{~cm}$, the iron plaque-like mottles may have been formed by hygrophytes other than cultivated rice. A few small iron plaque-like mottles can also be found in the plow layer soil. Iron minerals included in the root iron plaque are suggested to be ferrihydrite, lepidocrocite, and others (Kahn et al. 2016). A possible reason for the remaining brown, iron plaque-like mottles in the reduced subsoil may be depletion of easily decomposable organic matter in this soil horizon. The properties of these mottles were further examined microscopically.

The cylindrical iron mottles, shown in Fig. 5.6, are well developed and can be separated from a clod. Figure 5.6a shows a cross-section of an air-dried clod, which contains root iron plaque-like mottles of different sizes and colors. The browncolored larger mottles can be dug out from a field-moist clod, as shown in Fig. 5.6b, and were probably iron plaque formed around the roots of former vegetation. Figure 5.6c shows the gently washed iron plaque. It contains sand-size particles in the brown-colored area. The color distribution pattern is concentric; from the outside inward the color changes from yellowish brown to brown and gradually to light brown. Figure 5.6d shows a longitudinal section of the cylindrical iron mottle (Fig. 5.6c). The sand-sized particles and color distribution pattern observed in Fig. 5.6c can be ascertained in Fig. 5.6d. The distribution of sand-sized particles within the cylindrical iron mottle (Fig. 5.6c, d) suggests that oxygen transported through the plant roots diffused outside of the roots, oxidized ferrous iron around the roots, and precipitated hydrated iron oxides in the reduced soil environment. Over time, more ferrous iron probably diffused from the soil matrix and concentrated around the iron plaque, increasing its thickness. Similar and larger cylindrical root 

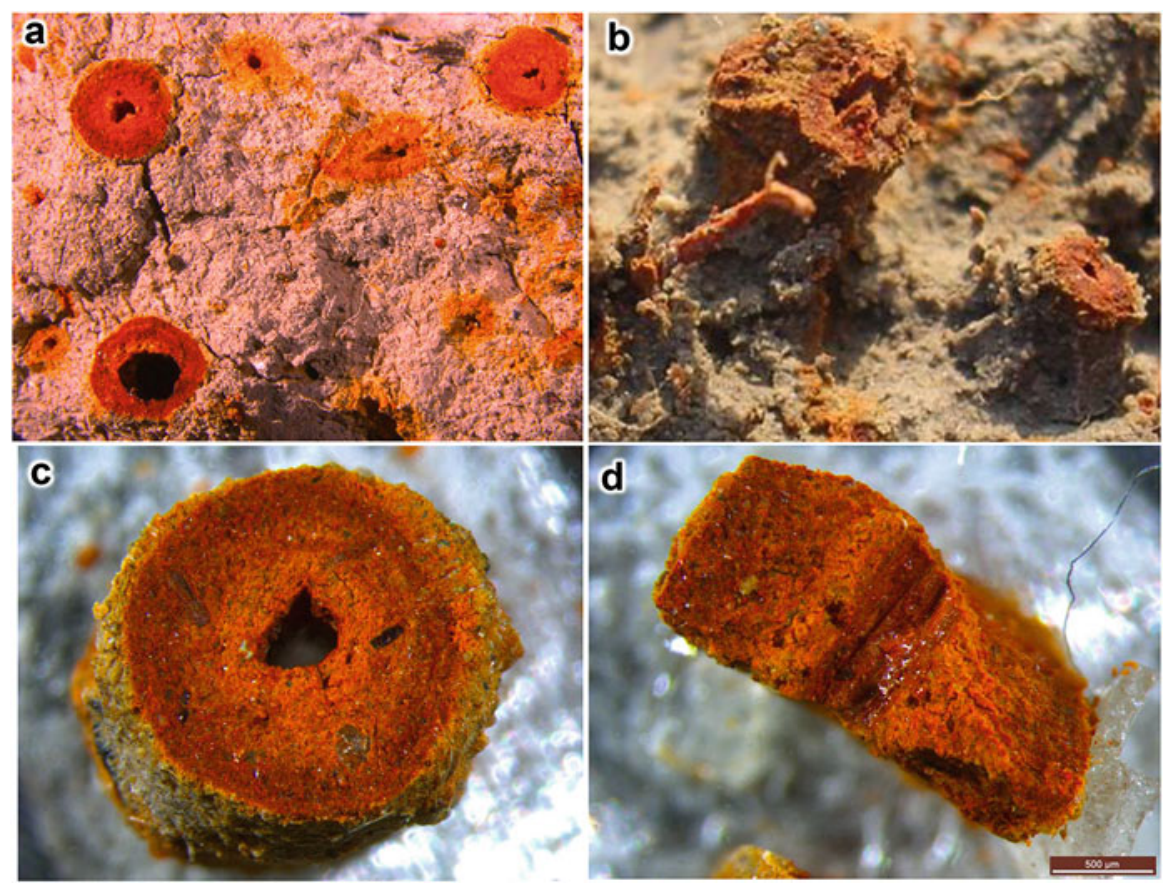

Fig. 5.6 Cylindrical iron mottles. (a) Iron mottles resembling root iron plaque, (b) digging the mottles out of the soil, (c) an iron mottle separated from the soil, (d) vertical section of the iron mottle in (c)

iron plaque has been reported from Pleistocene sediment in Aichi Prefecture, Japan (Yoshida and Matsuoka 2004).

A polished section was used to examine the elemental distribution in the cylindrical iron mottles. Figure 5.7a shows a cross-sectional scanning electron microscope (SEM) image of a cylindrical iron mottle, which appears as a bright and thick ring. The EDX spectra in Fig. 5.7b, c were obtained from the locations outlined in Fig. 5.7a by dashed squares (b) (cylindrical iron mottle) and (c) (bulk soil outside the iron mottle), respectively. The concentration of iron is much higher in the iron mottle than in the outer soil matrix. In contrast, the concentrations of $\mathrm{Al}$ and $\mathrm{Si}$ are similar, suggesting that the cylindrical iron mottle developed in the soil matrix directly outside the plant root. Element maps of Si (Fig. 5.7d) and Fe (Fig. 5.7e) support the interpretation of these EDX spectra. Although the Si concentration in the iron mottle appears to be slightly lower than that of the bulk soil, the distribution pattern of Si-rich particles in the iron mottle is the same as that of the bulk soil. The iron concentration in the iron mottle is significantly higher than that of the bulk soil, and the iron distribution pattern compares closely to the SEM image of the iron mottle (Fig. 5.7a). Potentially, the EDX spectrum for the iron mottle (Fig. 5.7b) has very small peaks of $\mathrm{P}$ and $\mathrm{S}$ that are lacking in the bulk soil EDX spectrum (Fig. 5.7c). 

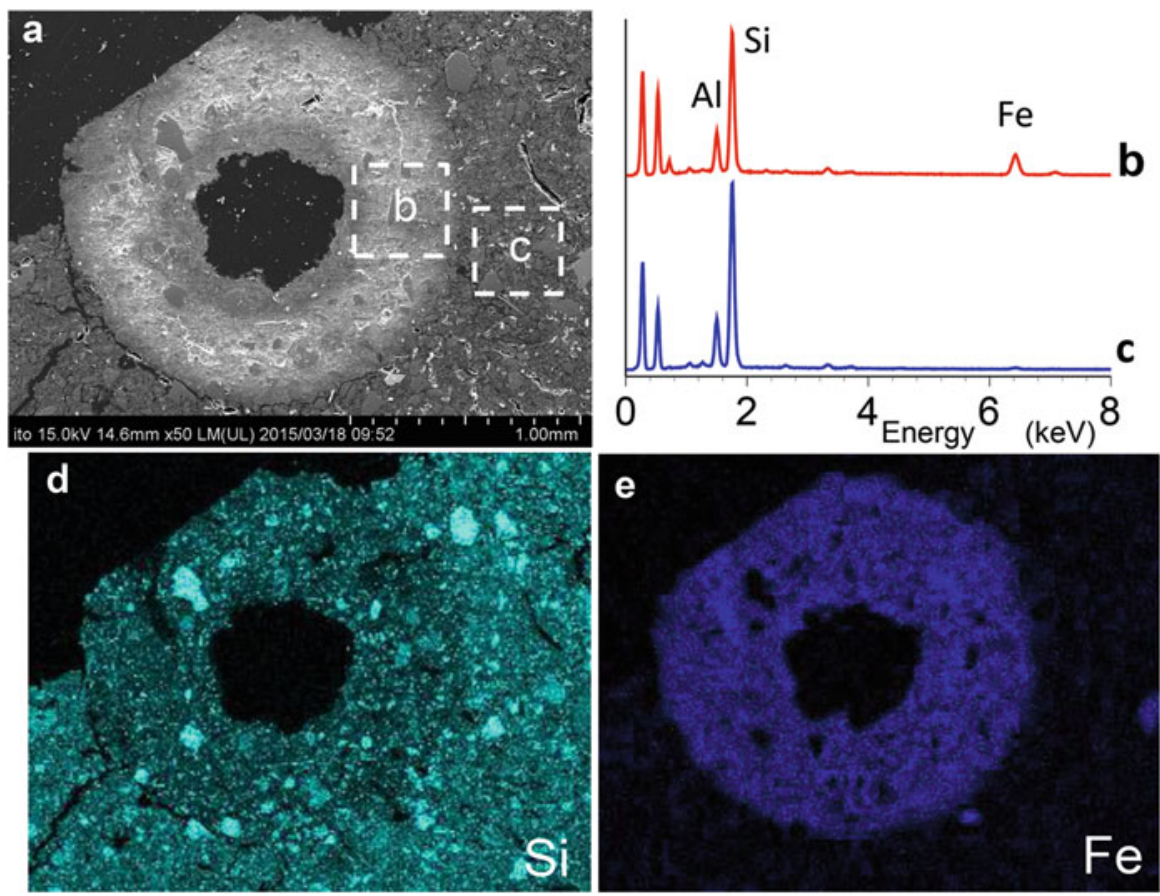

Fig. 5.7 SEM-EDX analyses of a cylindrical iron mottle using a polished section. (a) SEM image, (b and c) EDX spectra from the positions indicated by dashed squares (b) and (c), respectively, shown in (a), (d and e) Si and Fe element maps, respectively
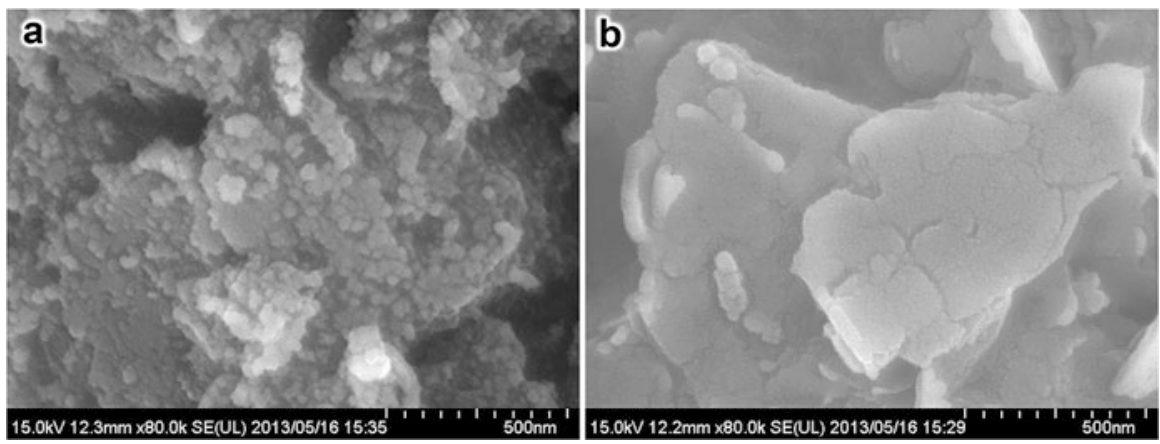

Fig. 5.8 Magnified SEM images. (a) cylindrical iron mottle, (b) bulk soil

As shown in Figs. 5.6 (color) and 5.7 (EDX spectra and Fe element map), differences in the distribution of iron between the iron mottle and bulk soil are evident. An additional difference between the mottle and bulk soil is observable in magnified SEM images (Fig. 5.8). Figure 5.8a shows that in the cylindrical iron mottle, aggregates of very fine spherical particles (poorly crystalline hydrated iron 

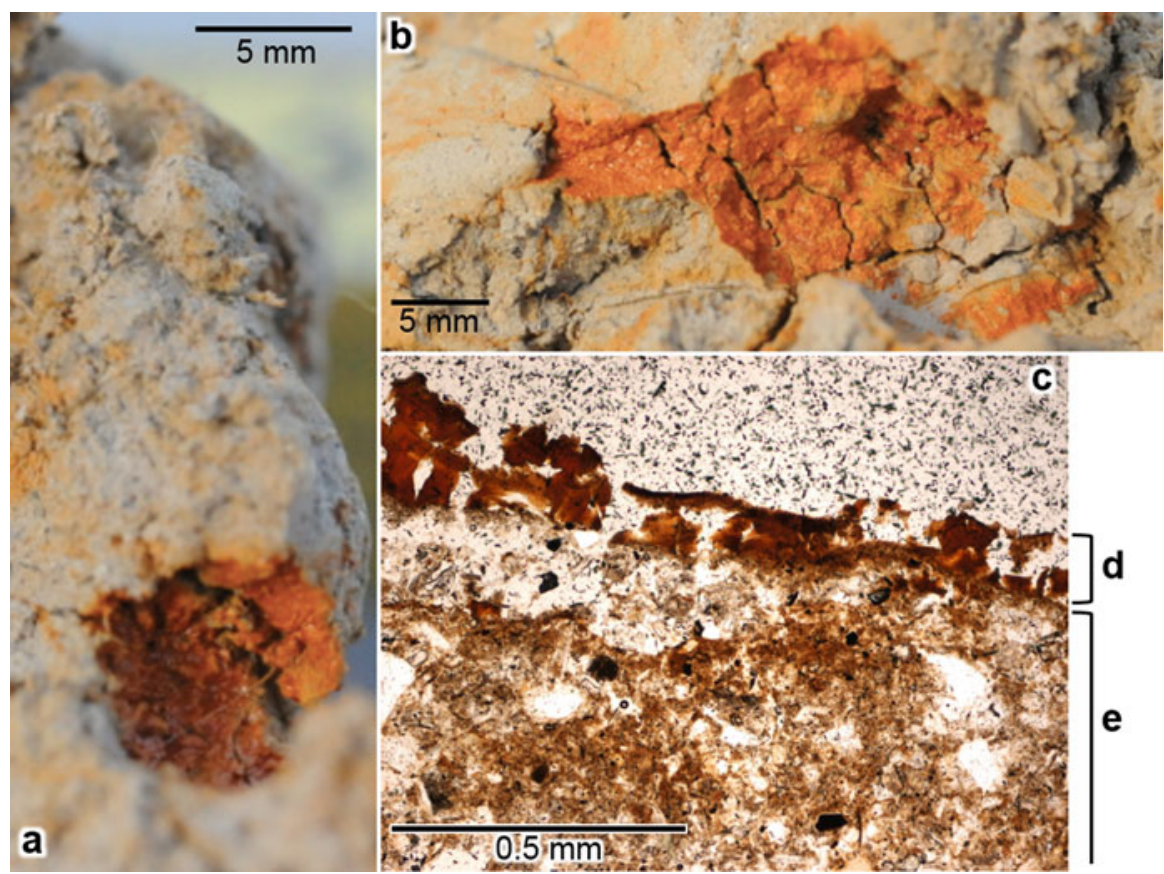

Fig. 5.9 Iron mottles coating the pore surfaces. (a) vesicular pore surface, (b) irregular pore surface, (c) thin section micrograph of the iron mottle (d) and bulk soil (e)

oxides) surround montmorillonite platy particles. In contrast, Fig. 5.8b shows that platy montmorillonite particles in the bulk soil lack these very fine spherical particles.

The next example of hydrated iron oxide taken from the plow layer soil (Fig. 5.5b) is iron mottles that resemble a coating of irregular or vesicular pore surfaces. Examples are shown in Fig. 5.9a (round vesicular shape) and (b) (irregular shape). These iron mottles, resembling a pore surface coating or lining, are more common inside the plow layer soil than on the soil surface where the soil is in direct contact with air. Considering the smoothly curved surfaces of these pores (Fig. 5.9a, b), they may have formed by gas $\left(\mathrm{CO}_{2}\right.$ or $\left.\mathrm{CH}_{4}\right)$ production from microbial activity. Examining the thin section prepared to show a cross-section of the iron coating (Fig. 5.9c) under plane polarized light, the brown-colored part (Fig. 5.9d), which is the pore surface coating, contains no sand-sized particles. In contrast, the bulk soil (Fig. 5.9e) contains many transparent sand-sized particles. This observation suggests that the hydrated iron oxide coating the pore surfaces was formed outside the bulk soil. This occurrence of hydrated iron oxide is different from the cylindrical iron mottles that were formed in the bulk soil around plant roots (Figs. 5.6, 5.7, and 5.8), although the cylindrical mottles are thicker than the mottles coating the pore surfaces. 


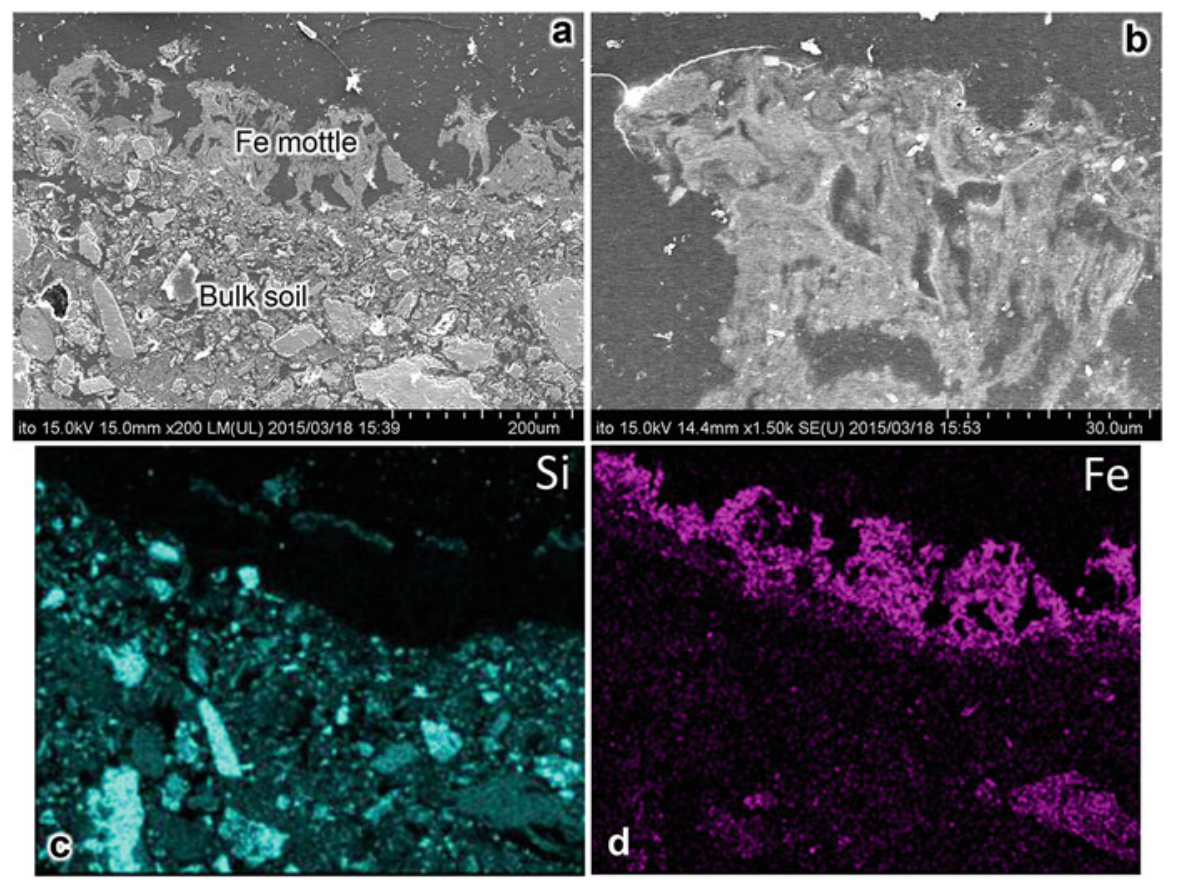

Fig. 5.10 Polished section of iron mottles coating the pore surfaces. (a) SEM image of polished section, (b) magnified SEM image of the iron mottle, (c and d) Si and Fe element maps, respectively

In order to further examine the elemental distribution in the mottles coating the pore surfaces, a polished section was prepared from a clod containing these mottles. Figure 5.10a shows a SEM image with similar magnification to the thin section (Fig. 5.9c). The thickness of the mottle is approximately $0.1 \mathrm{~mm}$. Many sand-size particles are observed in the bulk soil area, whereas the mottle area has a streak-like structure. The streak-like structure of the mottle tends to be oriented from the soil surface to the pore space (Fig. 5.10b). This streak-like structure is somewhat different from the aggregates shown in Fig. 5.8a, although the magnification is not the same. The Si element map (Fig. 5.10c) shows a lack of Si-containing minerals in the iron mottle. The Fe element map (Fig. 5.10d) shows that the area of high Fe concentration compares very closely to the iron mottle in the SEM image (Fig. 5.10a).

The differences in structure between the cylindrical iron mottles and the iron mottles coating the pore surfaces may be due to the pore space at the redox interface where $\mathrm{O}_{2}$ and $\mathrm{Fe}^{2+}$ meet. The former may have a barrier that prevents $\mathrm{Fe}^{2+}$ from diffusing smoothly inside the root. This barrier may be root sclerenchyma and/or exodermis. Consequently, oxygen diffuses into the bulk soil and hydrous iron oxide precipitates in the bulk soil. In contrast, the latter have space where hydrated iron 
oxide can precipitate outside the bulk soil. In the case of the iron mottles in the plow layer soil, phosphorus is also a significant constituent, as shown in Sect. 5.3.

\subsection{Vivianite}

As an iron phosphate mineral under reducing conditions, vivianite $\left[\mathrm{Fe}_{3}\left(\mathrm{PO}_{4}\right)_{2}\right.$. $6 \mathrm{H}_{2} \mathrm{O}$ ] has been found in sediments or organic soils under reducing conditions (Rothe et al. 2016). Here we introduce the formation and dissolution of vivianite in the plow layer soil of paddy fields. Vivianite is formed and dissolved according to the redox conditions of the soil. Vivianite is formed significantly in ordinarily P-enriched paddy field soils, whereas it is not formed in Andisol paddy fields.

\subsubsection{Detection of Vivianite in Paddy Field Soil}

Vivianite has previously been reported in the deep horizon, $1 \mathrm{~m}$ from the surface, of paddy field soil with high ground water level (Ito 1975). This site of vivianite presence is too deep to be related to rice cultivation, i.e., $\mathrm{P}$ fertilizer application in the paddy field. Subsequently, Wada et al. (1977) reported a vivianite-like material on rice roots using an optical microscope. Their finding was directly related to rice plants. Their observation was later confirmed using X-ray microdiffraction and SEM-EDX analyses on rice roots grown in pots (Nanzyo et al. 2010) and in ordinary paddy fields (Nanzyo et al. 2013). Figure 5.11a shows vivianite crystal aggregates formed on rice roots. The color is blue-green, which is due to partial oxidation of iron after exposure to air. Regarding the color change of vivianite after exposure to air, see Fig. 5.20. The powder XRD pattern obtained from the vivianite aggregates (Fig. 5.11b) by the microdiffraction method is significantly different compared to that obtained from a rice root with almost no vivianite crystals. The XRD pattern shown in Fig. 5.11b is identical to the reference XRD pattern for vivianite reported by Lehr et al. (1967) (Fig. 5.11c). Hence, the XRD analyses show that vivianite is dominant in the crystal aggregates (Fig. 5.11). Important conditions required to detect vivianite on rice roots are (i) lowland paddy field soils (not Andisols), (ii) duration of approximately one-and-a-half months after transplanting a rice seedling under continuous submergence, (iii) plant-available $\mathrm{P}$ level of plow layer soil higher than approximately $0.1 \mathrm{~g} \mathrm{P}_{2} \mathrm{O}_{5} \mathrm{~kg}^{-1}$ as determined by the Truog method, (iv) washing of rice roots to remove soil soon after sampling, (v) air-drying of washed roots, and (vi) magnifying glass with magnification factor of greater than 30 times.

The elemental composition of a vivianite crystal aggregate was examined (Fig. 5.12). From the crystal aggregate (Fig. 5.12a), dashed square b was selected, and the corresponding EDX spectrum (Fig. 5.12b) showed that the crystal aggregate 


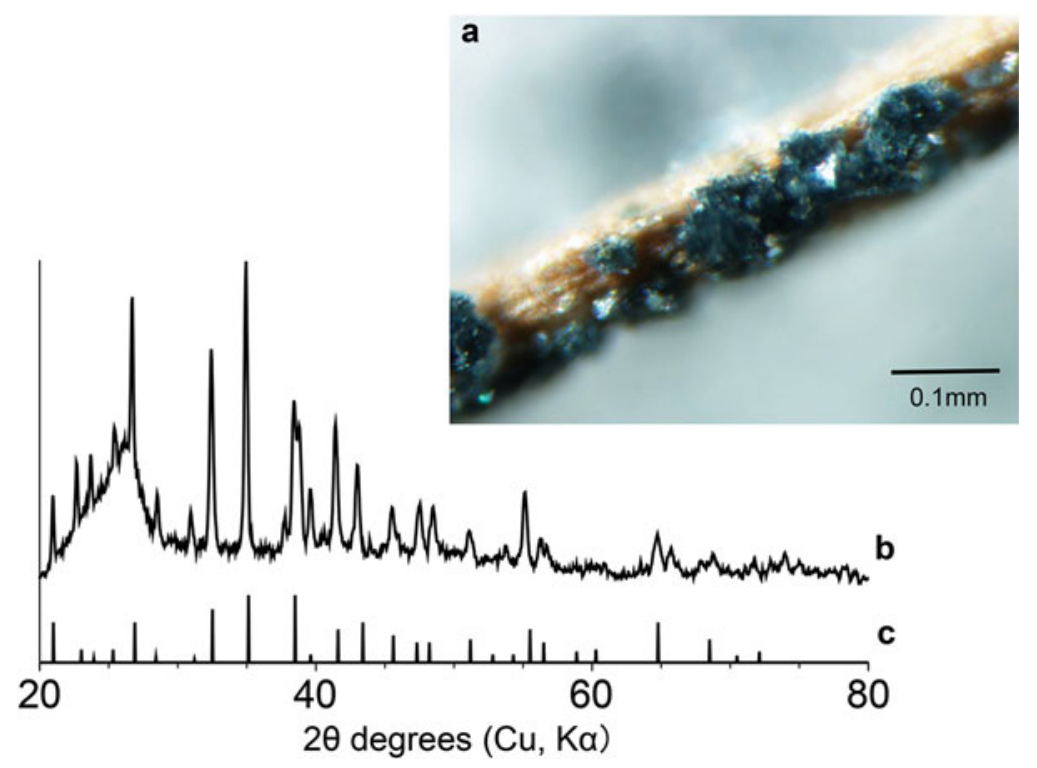

Fig. 5.11 Detection of vivianite by X-ray microdiffraction. (a) optical micrograph of vivianite formed on rice roots, (b) XRD pattern of vivianite crystal aggregates, (c) reference XRD pattern of vivianite (Lehr et al. 1967)

dominantly consists of Fe and P. Element maps of P (Fig. 5.12c) and Fe (Fig. 5.12d) compare closely to the SEM image (Fig. 5.12a), indicating that the crystal aggregate surrounding the root in Fig. 5.12a is dominantly composed of vivianite.

Although the surfaces of rice roots in the reduced paddy field soil are covered with oxidized iron plaque, some of this plaque may be reduced with aging. During plaque formation on rice roots, $P$ released by reduction of hydrated iron oxides in the soil can be sorbed and accumulated on the iron plaque, as described later in Sect. 5.3.3. With an increase in reducing conditions to the iron plaque, vivianite is formed. Since new rice roots develop in succession with an increase in tillering, and the redox conditions in the soil around roots may likely vary, for example, with depletion of easily decomposable organic matter, some iron plaque may remain until after the rice harvest.

As a result, considering that rice roots comprise a mixture of young and old specimens, the ratio of $\mathrm{P}$ in the vivianite form is only half of the $\mathrm{P}$ contained in rice roots (Nanzyo et al. 2013). The other half may be iron phosphate material that exists at the redox interface cells shown in Figs. 5.17 and 5.19, possibly the root sclerenchymatous layer and/or exodermis.

Under reducing conditions in soil, the content of ferrous salts other than vivianite may be considerable. The other ferrous salts are $\mathrm{Fe}(\mathrm{OH})_{2}$, siderite, and noncrystalline ferrous sulfide. Figure 5.13 compares the stability of these four ferrous salts in an approximately neutral $\mathrm{pH}$ range under hypothetical conditions (Nanzyo et al. 2010). 

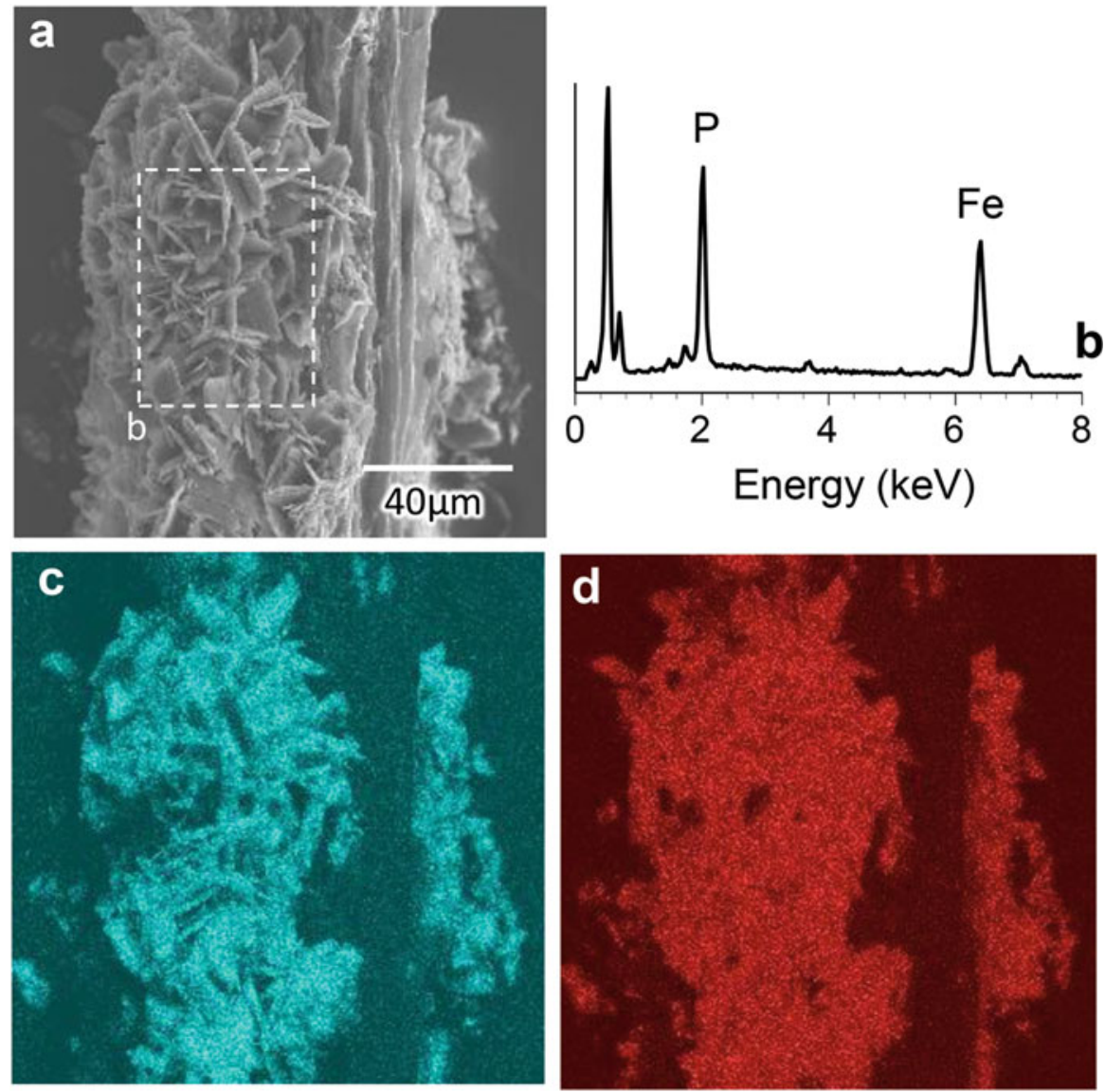

Fig. 5.12 Elemental composition of vivianite on a rice root. (a) SEM image of vivianite crystal aggregates formed on a rice root, (b) EDX spectrum for dashed square (b) shown in (a), (c, and d) P and $\mathrm{Fe}$ element maps of the crystal aggregates, respectively

In this diagram, a solid phase with a higher $\log \left\{\mathrm{A}_{\mathrm{i}}\right\} /\left\{\mathrm{Fe}^{2+}\right\}$ value is considered to be more stable than those with lower values, where $\left\{\mathrm{A}_{i}\right\}$ shows the formal activities of the solid phase in the same way as the activities of the solutes. Uncorrected equilibrium constants (ionic strength $=0$ ) were used for simplicity. The concentrations of total dissolved phosphorus $\left(\mathrm{P}_{\mathrm{T}}\right)$, sulfur $\left(\mathrm{S}_{\mathrm{T}}\right)$, and inorganic carbon $\left(\mathrm{C}_{\mathrm{T}}\right)$ were tentatively assumed to be $10^{-6}, 10^{-6}$, and $10^{-3}$ mol L ${ }^{-1}$, respectively. These values may vary widely with soil conditions and biological activity (Kirk 2004; Kyuma 2004), which may affect the results. Furthermore, the reported solubility product value for vivianite can vary by several orders of magnitude $\left(10^{-32}-10^{-36}\right)$ (Sadiq and Lindsay 1979; Stumm and Morgan 1996). This discussion about the relationship of these ferrous salts is made under these assumptions. The stability of FeS (amorphous) is the highest of the four salts. However, since the labile $\mathrm{S}$ content in the studied soil was 


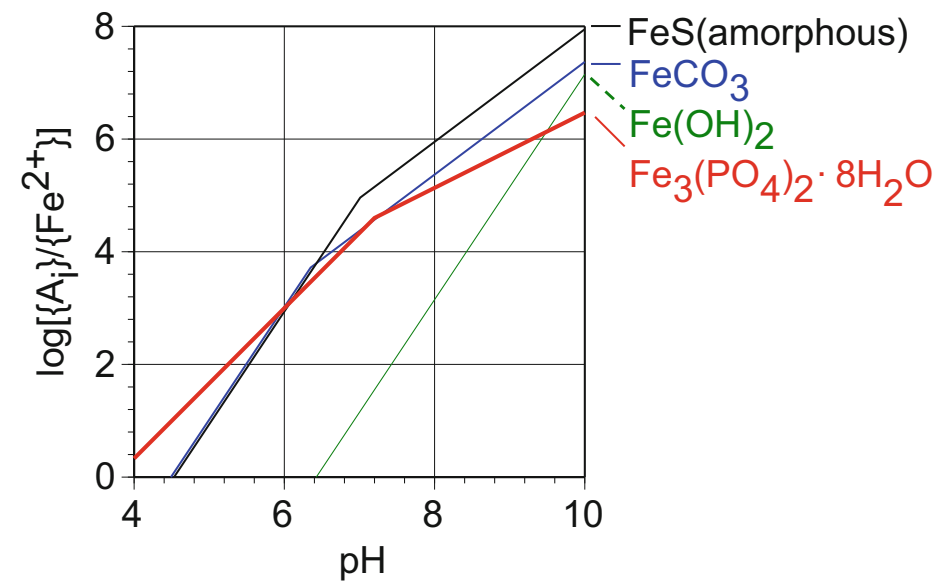

Fig. 5.13 Activity ratio diagram for $\mathrm{P}_{\mathrm{T}}=\mathrm{S}_{\mathrm{T}}=10^{-6} \mathrm{~mol} \mathrm{~L}^{-1}$ and $\mathrm{C}_{\mathrm{T}}=10^{-3} \mathrm{~mol} \mathrm{~L}^{-1}$ in a Fe-P$\mathrm{S}-\mathrm{C}$ system. $\left\{\mathrm{A}_{\mathrm{i}}\right\}$ shows the activities of the solid phase. Amorphous $\mathrm{FeS}$ and vivianite have been added to the activity ratio diagram for $\mathrm{Fe}(\mathrm{OH})_{2}$ and $\mathrm{FeCO}_{3}$ described by Stumm and Morgan (1996)

much less than $\mathrm{Fe}_{\mathrm{o}}$, enough ferrous iron was still available for the formation of other solid phases, such as $\mathrm{FeCO}_{3}$ and vivianite, in the neutral soil $\mathrm{pH}$ range under reducing conditions. The activity ratios of the latter two minerals are shown to be relatively similar in Fig. 5.13. Both of these minerals may form if enough ferrous iron is still available for the mineral with the lower stability. Thus, our present observation of solid phases in the reduced soil is compatible with reported thermodynamic data and stability relationships.

\subsubsection{Effect of Water Management on Vivianite in Paddy Field Soil}

Indices of biologically available $\mathrm{P}$, such as Truog $\mathrm{P}$ or Bray No. $2 \mathrm{P}$, and dissolved $\mathrm{P}$ levels in soil water have been reported to increase under reducing conditions compared to those under oxidizing conditions (Shiga and Yamaguchi 1976; Kyuma 2004). Previous research has suggested that vivianite may be responsible for these observations. Heiberg et al. (2012) also considered vivianite to explain P behavior in soils under reduced conditions. Considering thermodynamic stability, vivianite is thought to form under reducing conditions and to dissolve after soil oxidation (Lindsay 1979); therefore, the vivianite content is most likely affected by the changing redox conditions in paddy field soils between submergence and drainage. Thus, the vivianite content of rice roots was examined under the three different water management schemes shown in Fig. 5.4. 


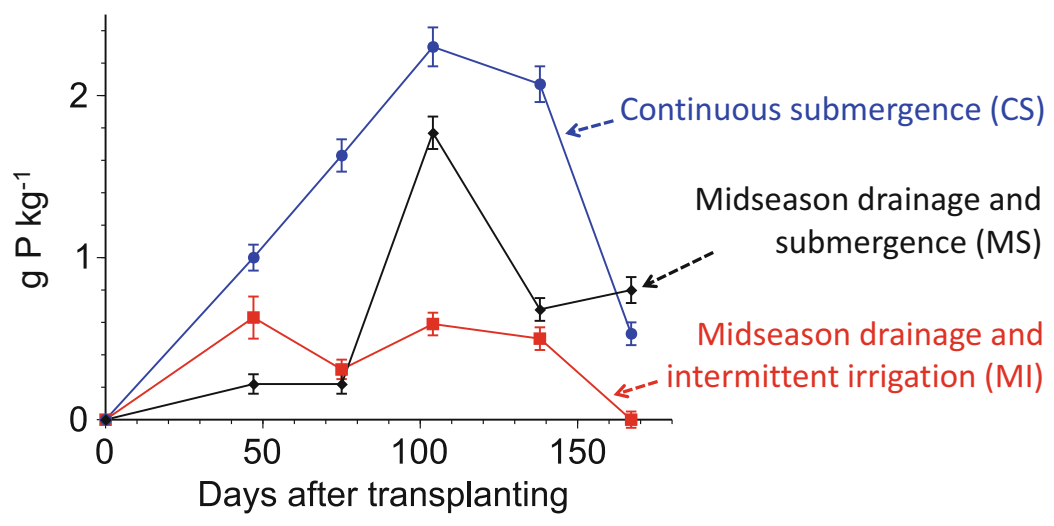

Fig. 5.14 Changes in the vivianite content of rice roots with three different water management schemes. The vivianite content of rice roots was estimated based on its property that the solubility of vivianite in mixed acid solution $\left(0.1 \mathrm{~mol} \mathrm{~L}^{-1} \mathrm{HCl}\right.$ and $1 \mathrm{~mol} \mathrm{~L}^{-1}$ acetic acid) greatly decreases after heating at $105{ }^{\circ} \mathrm{C}$ (Nanzyo et al. 2013). The error bars show the absolute deviation from the mean $(\mathrm{n}=2)$

Different water management schemes affected the vivianite content on rice roots (Fig. 5.14). The highest vivianite content was present in the continuous submergence (CS) plot. Following drainage, the vivianite content decreased with oxidation of the plow layer soil. The slow decrease in the vivianite content of the CS plot was possibly related to slow drainage and slow oxidation due to the lack of midseason drainage. In the midseason drainage and submergence (MS) plot, the vivianite content increased to a level almost similar to that of the CS plot at 104 days after transplanting (Fig. 5.14). Of the three plots, the vivianite content was lowest in the midseason drainage and intermittent irrigation (MI) plot. The Eh value in the MI plot tended to be higher following midseason drainage compared to the other plots (Fig. 5.4). The observed changes in the vivianite content on rice roots with water management scheme (Fig. 5.14) followed the changes in the Eh value (Fig. 5.4). These observations indicate that vivianite formation is strongly affected by water management and the redox conditions in the plow layer soil of paddy fields. According to Lindsay (1979), vivianite dissolution is facilitated by a decrease in ferrous iron concentration, and the generation of $\mathrm{P}$ sorption sites by the precipitation of hydrated iron oxides.

Considering Lindsay's interpretation about the behavior of vivianite after the cease of irrigation and subsequent oxidation of the plow layer soil of a paddy field, the $\mathrm{P}$ content of iron mottles in the plow layer soil was examined. Figure 5.15a shows part of a polished section of a clod with iron mottles coating the pore surfaces. The form of the iron mottle is similar to that shown in Figs. 5.9 and 5.10, the color is brown, and the thickness is $0.05-0.15 \mathrm{~mm}$. Figure $5.15 \mathrm{~b}-\mathrm{d}$ shows the element maps of $\mathrm{P}, \mathrm{Fe}$, and $\mathrm{Si}$ obtained from the dashed square area defined in Fig. 5.15e. The iron mottle layer contains $\mathrm{P}$ and $\mathrm{Fe}$ but no $\mathrm{Si}$, suggesting that $\mathrm{P}$ was sorbed by hydrated iron oxide that precipitated at the pore surface space, as observed in Figs. 5.9 and 


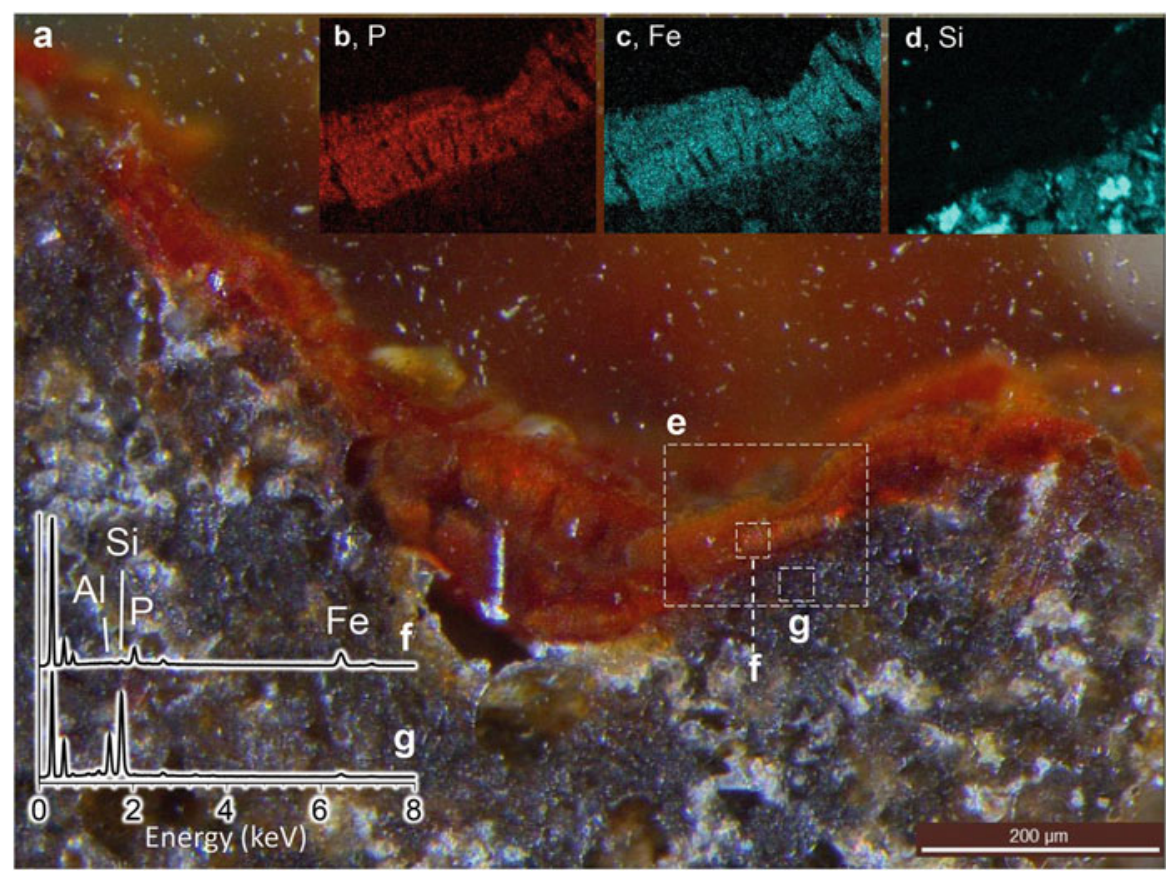

Fig. 5.15 Distribution of $P$ in the iron mottles and bulk soil. (a) polished section of soil clod with iron mottles coating the irregular pore surfaces, (b, c, and d) P, Fe, and $\mathrm{Si}$ element maps for the dashed square area defined in (e), (f,and $\mathbf{g})$ EDX spectra obtained from the dashed square areas (f) and g, respectively

5.10. There is also a streak-like structure in the iron mottle. The EDX spectra obtained for the dashed square areas (f) (iron mottle) and (g) (bulk soil) in Fig. 5.15 show that a significant content of $\mathrm{P}$ was detected in the iron mottle, whereas the $\mathrm{P}$ content in the bulk soil was very low. Hence, the iron mottle coating on the pore surfaces forms at least one of the P sink sites after dissolution of vivianite associated with soil oxidation.

\subsubsection{P Accumulation at Redox Interfaces of Rice Roots}

Cylindrical iron mottles or iron plaque developed on the roots of a hygrophytes introduced in Sect. 5.2 contained only a very small amount of P (Fig. 5.7b). Since the soil horizon was deeper than the plow layer soil, the effect of $\mathrm{P}$ fertilizer application was small. However, in the plow layer soil, the plant-available P level is high due to $\mathrm{P}$ fertilizer application. The rice roots are macroscopically brown in color (Fig. 5.16a), and iron plaque partly remains on the roots 1 month after harvest. From the washed and dried rice roots (Fig. 5.16a), a bundle was cut 5-7 cm from the root base, and a polished section was prepared to examine a cross-section of the iron 


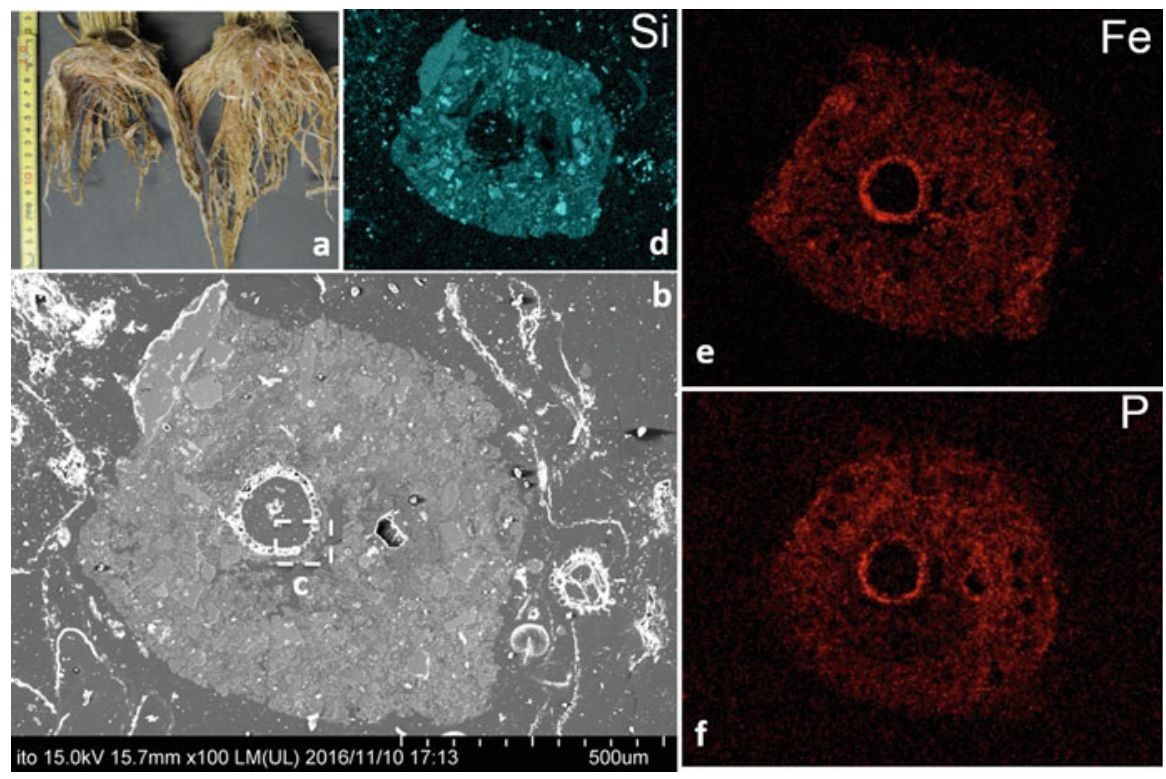

Fig. 5.16 Distribution of $\mathrm{P}$ in root iron plaque from the plow layer soil of a paddy field. (a) Rice roots washed out of the soil after harvest, (b) SEM image of polished cross-section of a rice root containing iron plaque, $(\mathbf{c})$ dashed square area for Fig. 5.17, (d, e, and f) element maps for $\mathrm{Si}, \mathrm{Fe}$, and $\mathrm{P}$, respectively

plaque. Figure 5.16b shows a SEM image of the rice root iron plaque. At the center, there is a thin rice root, of which only the exodermis-like layer and stele are likely to remain. Element maps of Si (Fig. 5.16d) and Fe (Fig. 5.16e) show that the iron plaque developed in the bulk soil around the rice root. These characteristics are similar to those shown in Fig. 5.7d, e. However, a difference observed in the Fe element map (Fig. 5.16e) is that the iron concentration in the exodermis-like layer is higher than that in the iron plaque developed outside the exodermis-like layer. Examining the $\mathrm{P}$ element map (Fig. 5.16f) shows that a P distribution pattern closely related to that for $\mathrm{Fe}$ was obtained. Hence, the iron plaque is the site of $\mathrm{P}$ accumulation in the plow layer soil, and these $\mathrm{Fe}$ and $\mathrm{P}$ accumulations may be converted to vivianite if the iron plaque is reduced. Remarkably, both Fe and $\mathrm{P}$ are highly accumulated in the exodermis-like layer in this example. Therefore, an area of the exodermis-like layer (dashed square in Fig. 5.16c) was magnified in Fig. 5.17a.

The EDX spectrum of the material inside the exodermis-like cells shows that it is similar to iron phosphate (Fig. 5.17b, Nanzyo et al. 2004). Since the material in each cell is localized toward the inner part of the root, the oxidizing power originated from within the root, possibly through the intercellular space. Based on the cell diameter, 10-17 $\mu \mathrm{m}$, these cells are exodermis rather than sclerenchyma (Kondo et al. 2000). The intracellular material also contains a small amount of $\mathrm{Ca}$, but almost no Si. Thus, the inner parts of the exodermis-like cells may be under a different environment from 


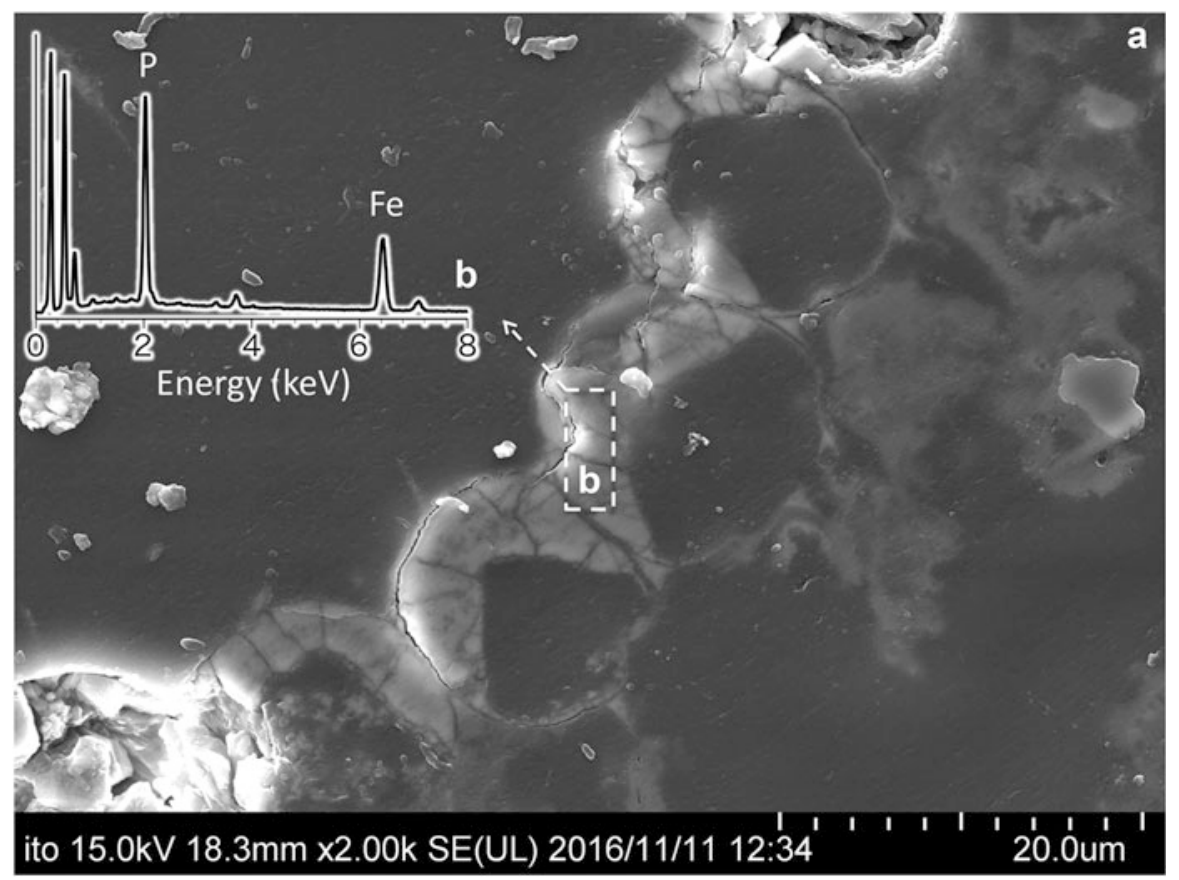

Fig. 5.17 Iron phosphate material in the exodermis-like cells. (a) magnified SEM image of the dashed rectangular area in Fig. 5.16c, (b) EDX spectrum obtained from the dashed rectangular area (b), shown in (a)

the outer parts, which is the site of iron plaque formation. The iron phosphate-like material is also different from vivianite because it does not show a blue color under the optical microscope. It was likely formed at the redox interface between the oxidative intercellular space inside the root and the reductive bulk soil outside the root. This iron phosphate-like material may be one of the reasons why the vivianite content of rice roots is as high as $50 \%$ even at the end of the paddy field submergence period (Nanzyo et al. 2013).

Figures 5.16 and 5.17 exhibit the thick iron plaque. However, when the rice roots are washed out of the soil, the number of brown roots without thick iron plaque is much greater than those with thick iron plaque. Figure $5.18 \mathrm{~b}$ shows an optical microscope photograph of the surface of a thick rice root, which displays a brown rod-like color pattern. Although this pattern is not observable with SEM, it is observable with EDX, as shown in the Fe element map (Fig. 5.18c) for the dashed square area outlined in Fig. 5.18d. The characteristic X-ray used for the EDX analyses provides information about deeper sites than the secondary electron beam used for SEM. These observations suggest that the brown rods are located under the exodermis cell walls. A similar pattern can be obtained for P, but it is less clear than that for Fe, suggesting that the Fe concentration in the brown rods is higher than that 


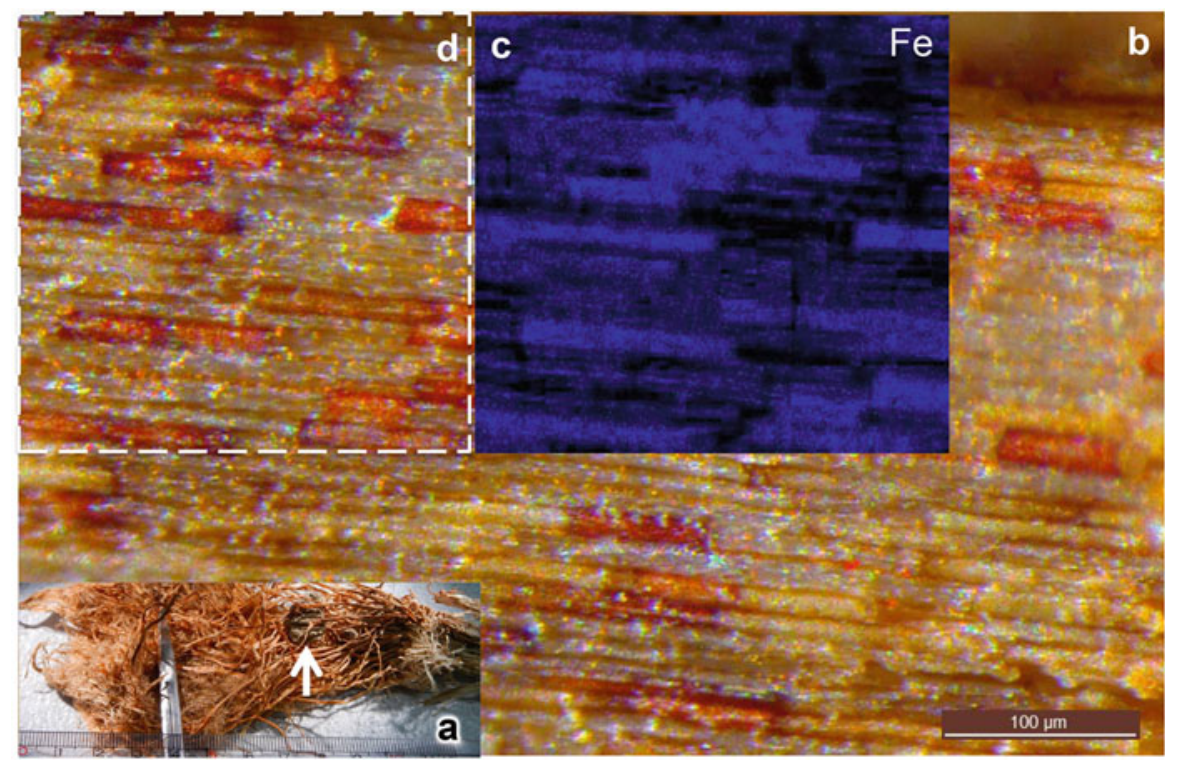

Fig. 5.18 Analysis of a brown thick rice root after rice harvest. (a) Air-dried rice roots after harvest with an arrow showing the position of the sampled root piece, (b) optical micrograph of the rice root piece, (c) Fe element map for the dashed square area in (d)

of P. In order to examine these brown rods, the roots were treated with hot $\mathrm{H}_{2} \mathrm{O}_{2}$ to digest the cell walls.

Under the optical microscope, the digested roots showed brown rods, and light brown-colored or nearly transparent particles with irregular shapes (Fig. 5.19a). After selecting a dashed square area (Fig. 5.19b), a SEM image (Fig. 5.19c) as well as element maps of Fe (Fig. 5.19d), Si (Fig. 5.19e), and P (Fig. 5.19f) were obtained. Integrating these results showed that the brown rods and particles are rich in Fe and $\mathrm{P}$, suggesting that they are composed of hydrated iron oxide and sorbed phosphate. Hence, it is probable that the brown rods observed on the root surface (Fig. 5.18b) are the brown rods observed in Fig. 5.19a. These brown rods were formed at the interface between oxidizing conditions inside the roots and reducing conditions outside the roots. The diameter $(15 \mu \mathrm{m})$ of the large brown rods suggests that they were formed inside the exodermis cells (Kondo et al. 2000). The longevity of P-rich hydrated iron oxide inside the sclerenchymatous cells and/or exodermis cells, and iron plaque, may depend on the intensity of aeration through the intercellular space, and the reducing conditions in the soil. Nearly transparent particles observed in Fig. 5.19a, b appear to be phytoliths. 


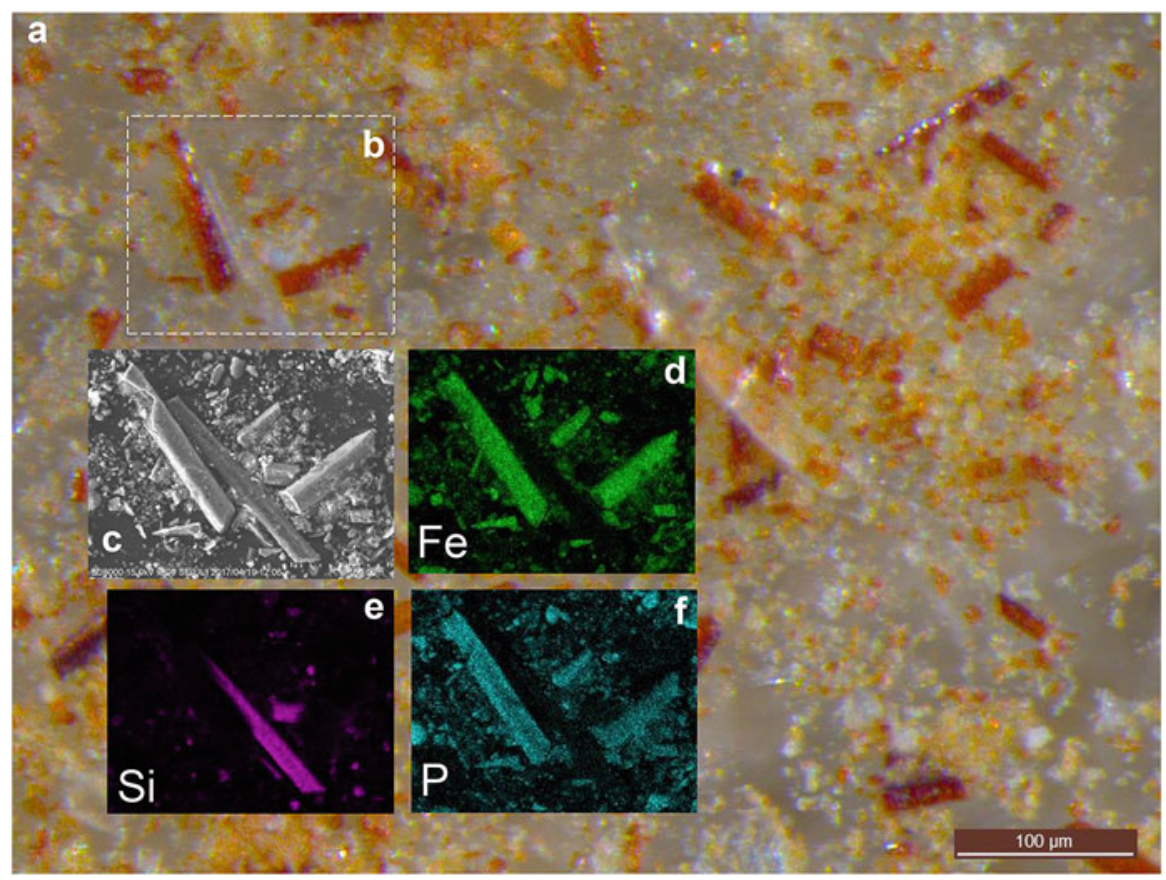

Fig. 5.19 Analyses of brown rice roots after rice harvest. (a) Optical micrograph of $\mathrm{H}_{2} \mathrm{O}_{2}$ digestion residue of rice roots, (b) dashed square area chosen for SEM-EDX analyses, (c) SEM image of the area outlined in $(\mathbf{b}),(\mathbf{d}, \mathbf{e}$, and $\mathbf{f})$ element maps for $\mathrm{Fe}, \mathrm{Si}$, and $\mathrm{P}$, respectively

\subsubsection{Vivianite Formation in Bulk Soil}

Figures 5.11 and 5.12 showed vivianite formation on rice roots. An advantage of using rice roots for vivianite detection is the simplicity of separating vivianite from soil. In addition, iron plaque around rice roots was the site of $\mathrm{P}$ accumulation under reducing soil conditions, which is preferable for vivianite formation, as discussed above. Incidentally, the occurrence of vivianite crystals on the rice roots suggests that parts of them are growing from exodermis-like cells toward the bulk soil. It appears that vivianite can be formed in bulk soil (Zelibor et al. 1988). In fact, vivianite crystals form aggregates larger than $0.05 \mathrm{~mm}$ in diameter. By using soil with a particle size of less than $0.038 \mathrm{~mm}$, vivianite crystal aggregates can be separated from the fine soil fraction using a $0.053 \mathrm{~mm}$ sieve.

Figure 5.20a shows vivianite crystal aggregates separated from the plow layer soil of a paddy field under submergence after incubation for 30 days at $30^{\circ} \mathrm{C}$. Vivianite crystals are colorless immediately after separation from the incubated soil. Subsequently, the color of the vivianite crystals slowly turns blue (Fig. 5.20b) by partial oxidation of $\mathrm{Fe}^{2+}$ in air (Garnd and Lavkulich 1980). Since other soil minerals are included in the crystal aggregates, the vivianite content of these aggregates is approximately $40 \%$. 


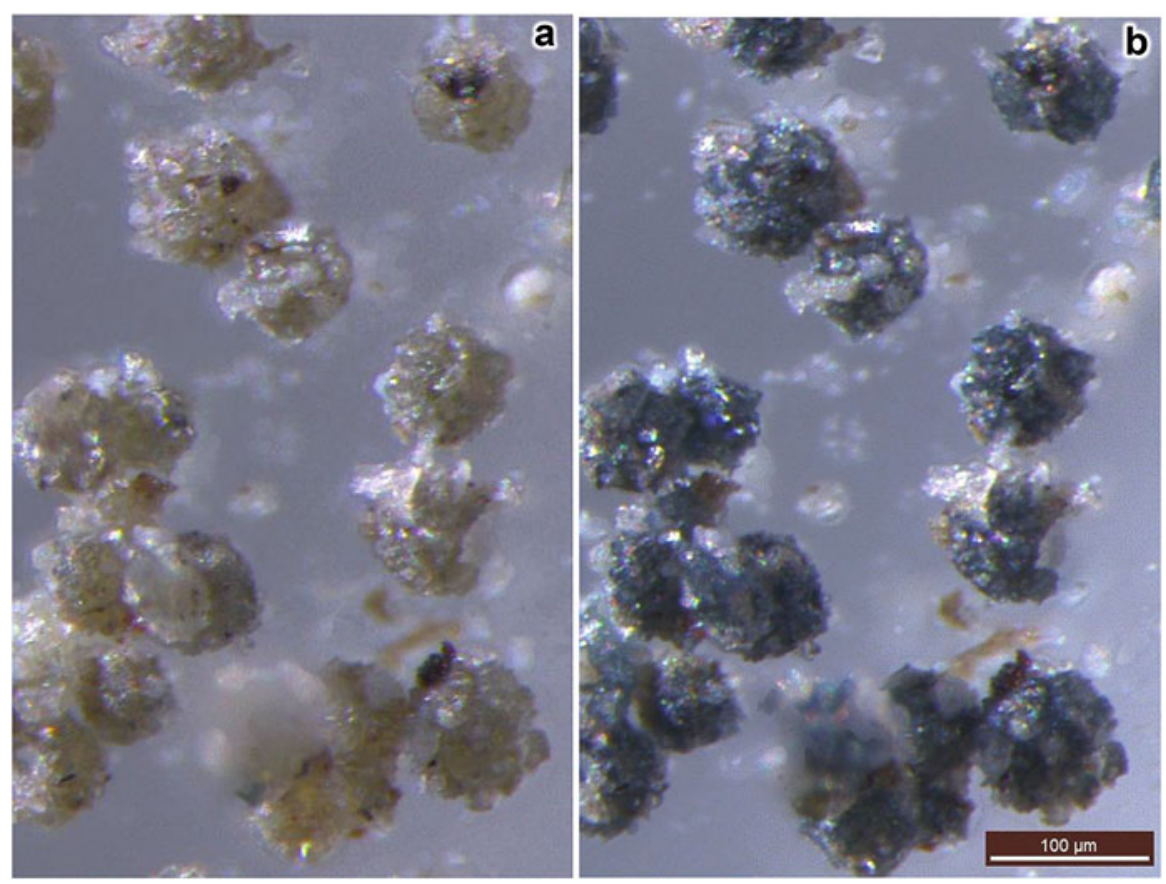

Fig. 5.20 Optical micrographs of vivianite crystal aggregates. (a) Immediately after separation from soil incubated for 30 days at $30^{\circ} \mathrm{C}$, (b) after allowing to stand for $8 \mathrm{~h}$ at approximately $25^{\circ} \mathrm{C}$

Vivianite forms in bulk soil under reducing conditions. Vivianite may affect the $\mathrm{P}$ dynamics in the plow layer soil of paddy fields (Walpersdorf et al. 2013). In a lowland paddy field soil, the $\mathrm{Fe}_{\mathrm{o}}$ content is typically much higher than $\mathrm{Al}_{\mathrm{o}}$. Under oxidizing conditions, active $\mathrm{Fe}$ materials in the plow layer soil play a major role in sorbing P from fertilizers. The P concentration in the soil solution increases with soil incubation under submergence (Shiga 1973). In that previous study, although vivianite formation was not confirmed, it is probable that the increase in $\mathrm{P}$ concentration was related to vivianite formation. However, the formation of vivianite contributes to retain $\mathrm{P}$ in the plow layer soil of paddy fields after releasing $\mathrm{P}$ from active $\mathrm{Fe}$ materials.

It is believed to be effective to study the factors affecting the formation and dissolution of vivianite to control P dynamics, and to increase P efficiency, in the plow layer soil of paddy fields. Although to date it has been difficult to artificially extract $\mathrm{P}$ from paddy fields, vivianite can at least theoretically be separated from soil. Magnets can also be used to collect vivianite aggregates from incubated paddy field soil. 


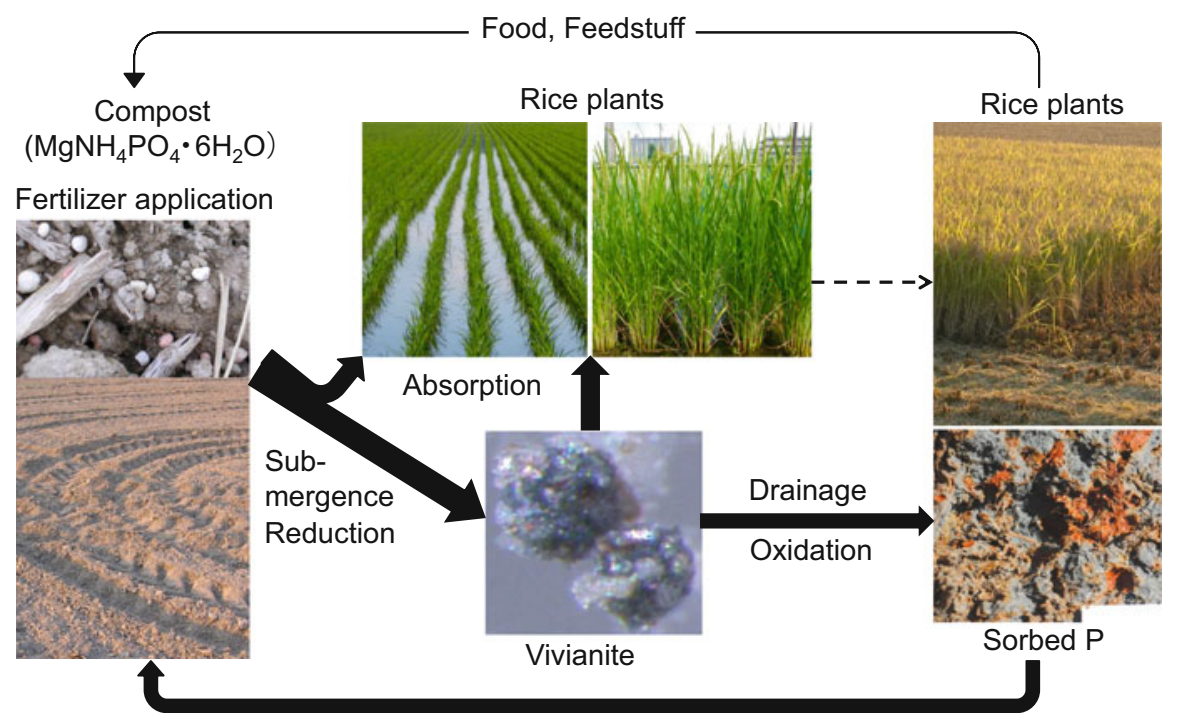

Fig. 5.21 Schematic P cycle in paddy fields of lowland

\subsubsection{P Cycle in Irrigated Lowland Paddy Field Soil}

The above-mentioned redox reactions related to $\mathrm{P}$ are outlined as the $\mathrm{P}$ cycle of rice production in Fig. 5.21. Starting with $\mathrm{P}$ fertilizer application to the plow layer soil (Fig. 5.21, left), the applied $\mathrm{P}$ is sorbed by active Fe minerals. Under submergence, $\mathrm{P}$ is partly absorbed by rice plants, and remaining reductant-soluble $\mathrm{P}$ is mainly converted to vivianite (Fig. 5.21, lower center), which is rice plant-available. Part of the $\mathrm{P}$ can be stored as P-rich hydrated iron oxides in sclerenchymatous and/or exodermis cells, and iron plaque. After irrigation is ceased, vivianite is dissolved and $\mathrm{P}$ is sorbed by hydrated iron oxides to give $\mathrm{P}$-rich hydrated iron hydroxide and iron mottles (Fig. 5.21, lower right). Approximately three-quarters of the $\mathrm{P}$ absorbed by rice plants is transferred to rice grain, and used as food for humans or feedstuff for animal production. The $\mathrm{P}_{2} \mathrm{O}_{5}$ concentration in chicken manure and swine manure is as high as $5-6 \%$ on a dry-weight basis (Komiyama et al. 2013). The major constituent form of $\mathrm{P}$ is $\mathrm{MgNH}_{4} \mathrm{PO}_{4} \cdot 6 \mathrm{H}_{2} \mathrm{O}$ (see Sect. 6.3), which is also available for rice plants, although the application of compost to paddy fields is uncommon in Japan at present. Rice straws are, in many cases, cut, sprayed on the soil surface, and then plowed into the soil. In this way, the remaining $\mathrm{P}$ in the rice straws and roots is returned to the plow layer soil. 


\subsection{Siderite}

Siderite $\left[\mathrm{FeCO}_{3}\right]$ is sometimes found in the subsoil of poorly drained paddy fields as white soft or firm nodules. Relatively large siderite nodules were found in a paddy rice field in Miyagi Prefecture, Japan (Fig. 5.22a). Since the paddy field was used for soybean cultivation at the time of sampling, the plow layer soil was brown in color. At depths of $15 \mathrm{~cm}$ or deeper, the soil color was bluish gray, indicating reduced conditions. Siderite was found at a depth of $40-50 \mathrm{~cm}$ below the surface (indicated
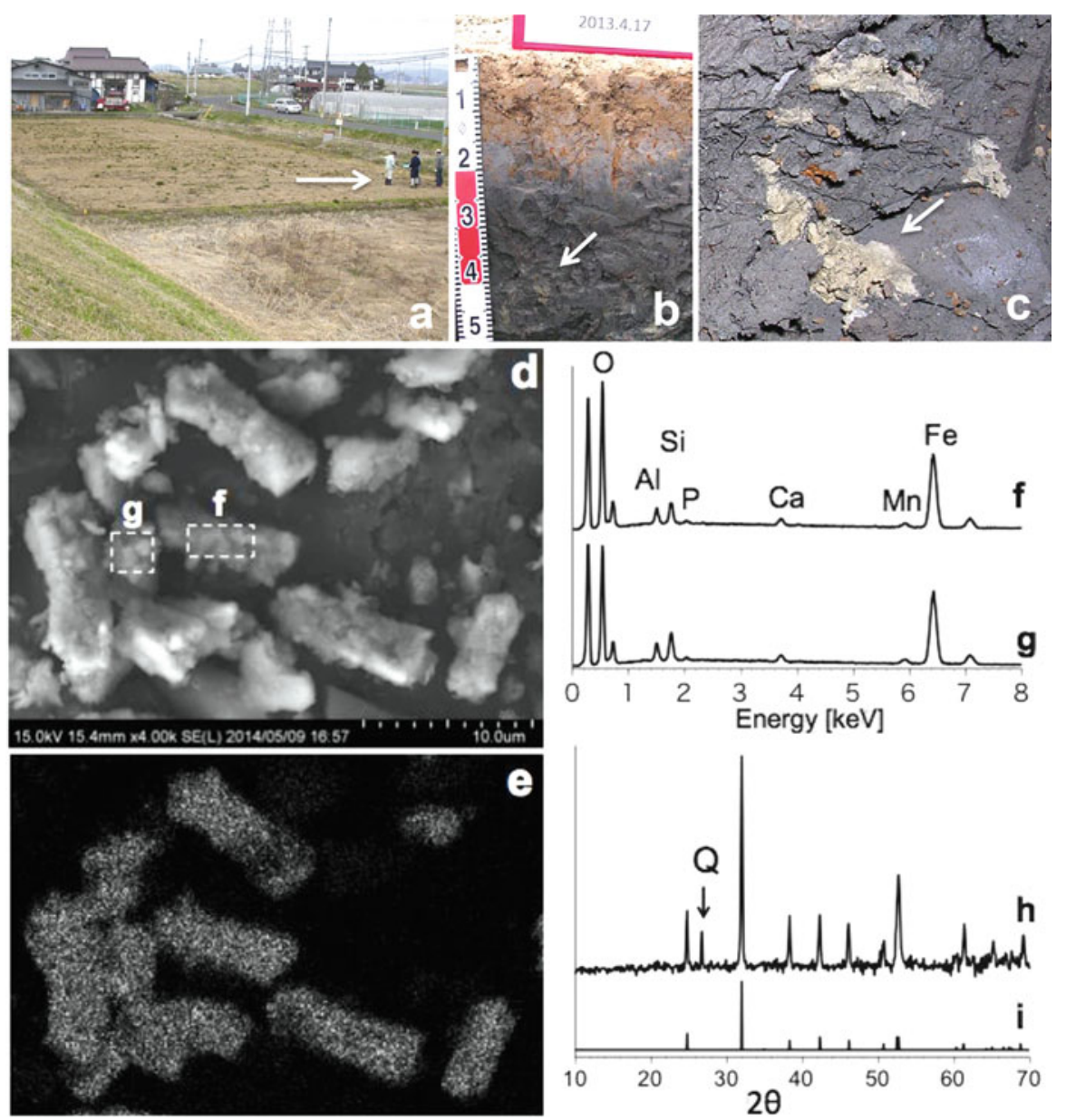

Fig. 5.22 Siderite in the subsoil of a poorly drained paddy field. (a) Sampling site (arrow shows the pedon site), (b) soil profile (arrow shows a siderite-rich horizon), (c) close-up of the siderite-rich horizon (arrow shows an example of a siderite-rich patch), (d) SEM image, (e) element map of Fe, (f and g) EDX spectra for selected areas (f) and (g) shown in (d), (h) XRD pattern of siderite from the paddy field subsoil where $\mathrm{Q}$ denotes a diffraction peak from quartz, (i) reference XRD data from Brindley and Brown (1980) 
by the arrow in Fig. 5.22b). Magnified, the siderite-rich part was identified as firm gray-colored concretions, as shown in Fig. 5.22c. The siderite concretion was composed of an aggregate of small rod-like particles (Fig. 5.22d), as supported by the Fe element map (Fig. 5.22e). EDX spectra (Fig. 5.22f, g) were obtained from the dashed square areas identified in Fig. 5.22d. They show that Fe is the major element other than $\mathrm{C}$ and $\mathrm{O}$, which are also elemental components of siderite.

The powder XRD pattern of the siderite concretion (Fig. 5.22h) is similar to that of reference siderite (Fig. 5.22i), although a small amount of quartz was also detected. The SEM observation also showed platy clay particles around the siderite (Togami et al. 2017), suggesting that the siderite nodules grew in the bulk soil.

Siderite in forms other than that shown in Fig. 5.22c, $d$ were found in the same soil horizon, where it appears that siderite is filling the pores of root iron plaque. Figure 5.23a shows a SEM image of one example, and Fig. 5.23b, c shows the Si and Fe element maps, respectively. The EDX spectra (Fig. 5.23d, e) were obtained from

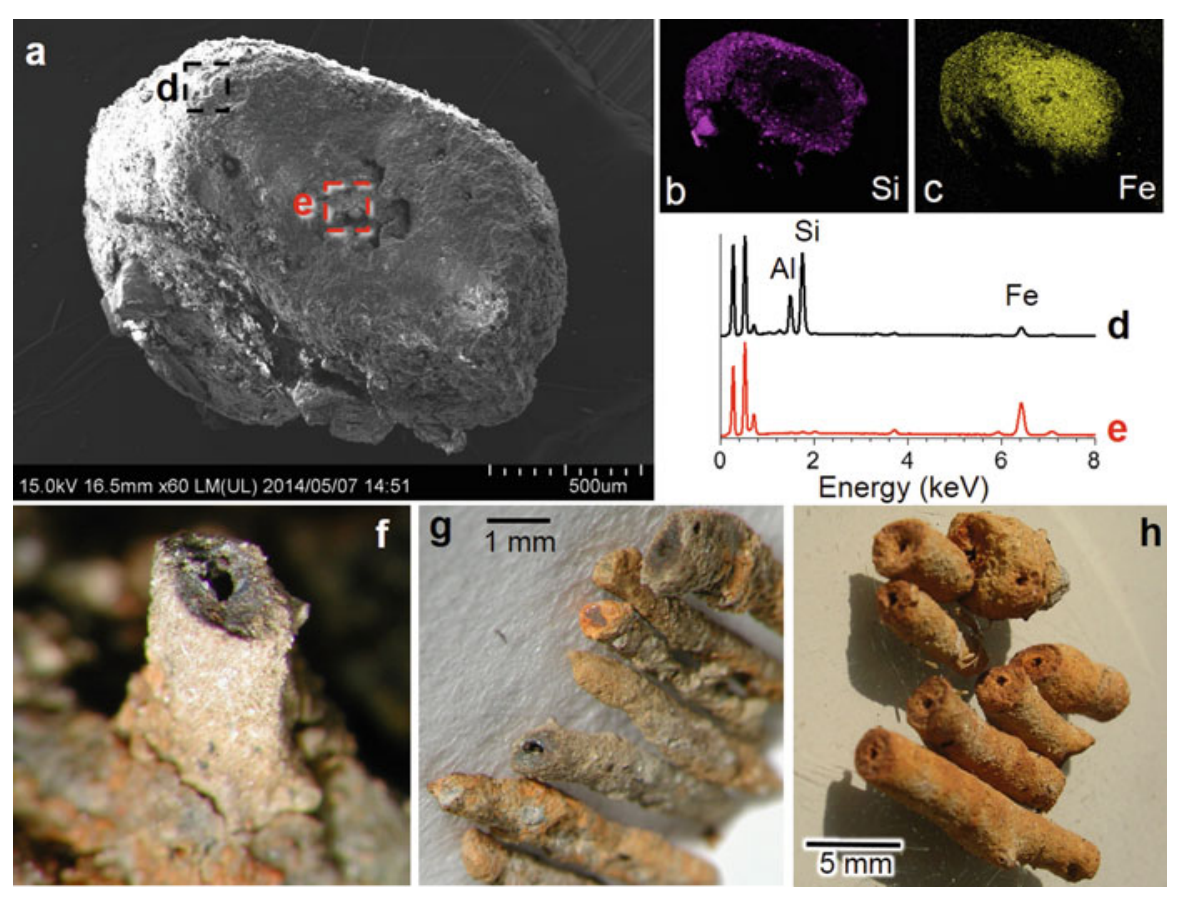

Fig. 5.23 Siderite resembling a filling pseudomorph separated from the soil profile shown in Fig. 5.22b at a depth of 40-50 cm. (a) SEM image, (b and c) Si and Fe element maps, respectively, (d and e) EDX spectra for the dashed areas (d) and (e), respectively, identified in (a), (f) an example of siderite having a central pore, (g) optical photographs of several rod-like siderites found at the same depth in Fig. 5.22b, (h) optical photograph of iron mottle-like root iron plaque found at a depth of $20-25 \mathrm{~cm}$ from the same soil profile as that shown in Fig. 5.5 
the dashed square areas (d) and (e), respectively, shown in Fig. 5.23a. These results suggest that the outer part of the siderite rod mainly consists of aluminosilicates accompanied by hydrated iron oxide (Fig. 5.23d), and that the central part consists of siderite (Fig. 5.23e). The central pore was almost entirely filled with siderite. Figure 5.23f shows an optical micrograph of a similar rod. Although it has the central pore, the color of the cross-section is dominantly grayish. Several similar rods were separated from the same horizon, of which some were light brown and others were grayish in color (Fig. 5.23g). These rods appear to be formed from root iron plaque (Figs. 5.23h and 5.6), although the latter is more accurately cylindrical.

\subsection{Pyrite and Related Sulfur-Containing Inorganic Constituents}

Sulfur is an essential element of organisms. It is sensitive to redox reactions in soil and exists as both inorganic and organic constituents in soil. In this section, two sulfides and one sulfate are introduced. Although gypsum is also an important sulfate in soil, it is mainly introduced in Sect. 6.2.

\subsubsection{Noncrystalline Iron(II) Sulfide}

Dark-colored areas are sometimes found in submerged soil, particularly when sulfate-containing fertilizers are applied. Figure 5.24a shows rice cultivation with a large amount of gypsum in a glass container, such that roots can be observed occasionally, although the glass container was covered with a dark sheet to avoid growth of photosynthetic organisms on the inner surface. Figure 5.24b shows a close-up photograph of roots at the middle depth of the container. The thick roots are mostly brown, whereas thin lateral roots are mostly black. If there is no significant difference in organic matter supply to microorganisms between the thick and thin roots, the air supply to the thin roots is probably more restrictive than that to the thick roots (Trolldenier 1977). The deeply dark color of the fine roots suggests diffusion of iron and sulfur to the thin roots due to the low solubility of the precipitate. Figure 5.24c shows a cross-section of the soil with roots. The upper $4-5 \mathrm{~cm}$ is an oxidizing layer. Roots are distributed more along the glass container than in the bulk soil. Below the oxidizing layer, the color of both the reducing layer and roots in the soil is dark.

The dark-colored material is noncrystalline ferrous sulfide. After the roots were washed, they were freeze-dried. An optical micrograph (Fig. 5.25a) shows that the thick roots are dark brown, and the thin lateral roots are dark. EDX spectra obtained from the dashed outlined areas of a lateral thin root (Fig. 5.25c) and the thick root 


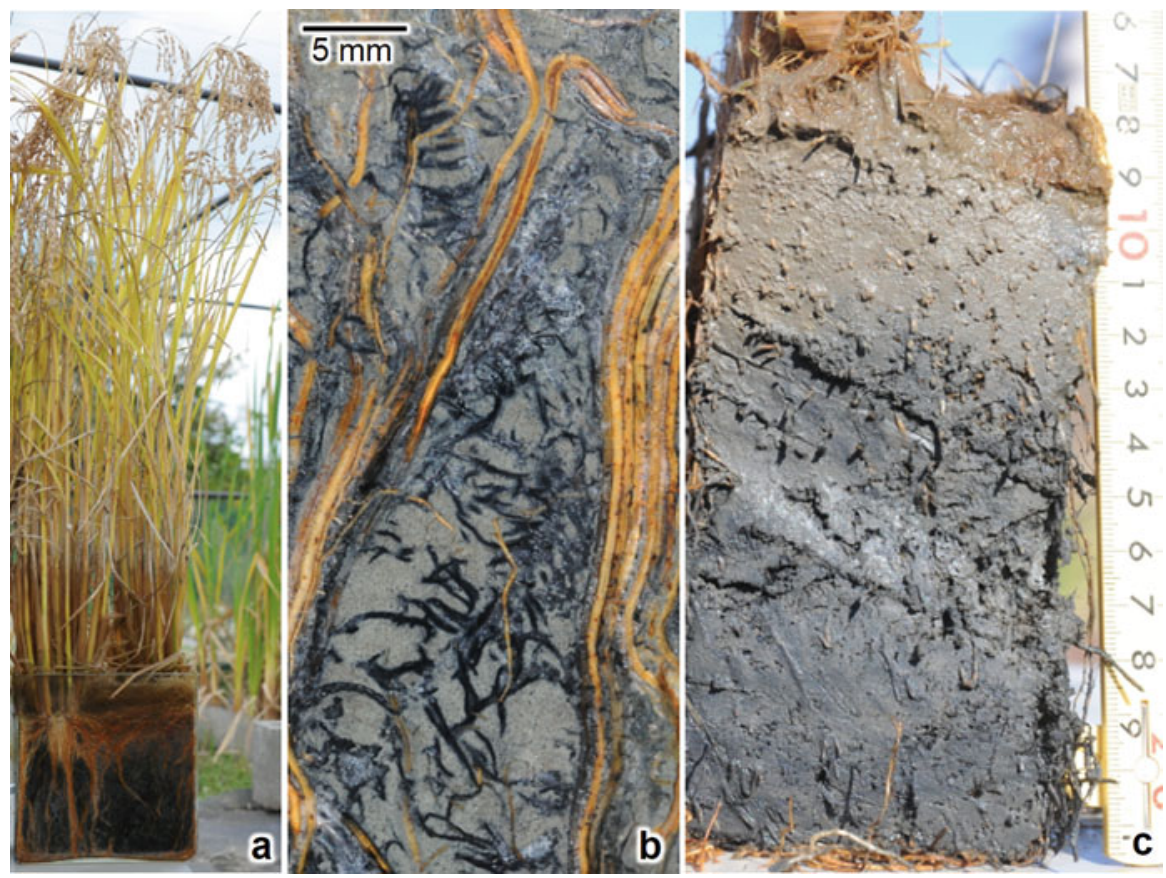

Fig. 5.24 Rice cultivation in a glass container using $1.6 \mathrm{~kg}$ soil with $\mathrm{N}, \mathrm{P}, \mathrm{K}$ fertilizers and $8 \mathrm{~g}$ $\mathrm{CaSO}_{4} \cdot 2 \mathrm{H}_{2} \mathrm{O}$. (a) soil and rice plants at harvest time, (b) close-up photograph of rice roots darkened by noncrystalline ferrous sulfide, $(\mathbf{c})$ cross-section of soil removed from the glass container

(Fig. 5.25d) show that the dark material is noncrystalline ferrous sulfide. The $\mathrm{S}$ and Fe counts are much higher for the thin root than those for the thick root, in accordance with the intensity of dark color. However, a magnified SEM image (Fig. 5.25e) of the thin-root dashed area (Fig. 5.25c) shows only the root surface, possibly due to the very small particle size of noncrystalline ferrous sulfide (Fanning et al. 2002). The root surface appears as epidermis and/or exodermis from which cells were sloughed off. If the washed dark roots were left to stand in air, color of the noncrystalline iron sulfide easily disappeared in a day due to oxidation.

\subsubsection{Pyrite}

Pyrite is ferrous disulfide $\left[\mathrm{FeS}_{2}\right]$. Noncrystalline ferrous sulfide may be a precursor of pyrite (Fanning et al. 2002). Pyrite may occur in newly reclaimed land from drainage or construction, and in the deep horizons of acid sulfate soil. 


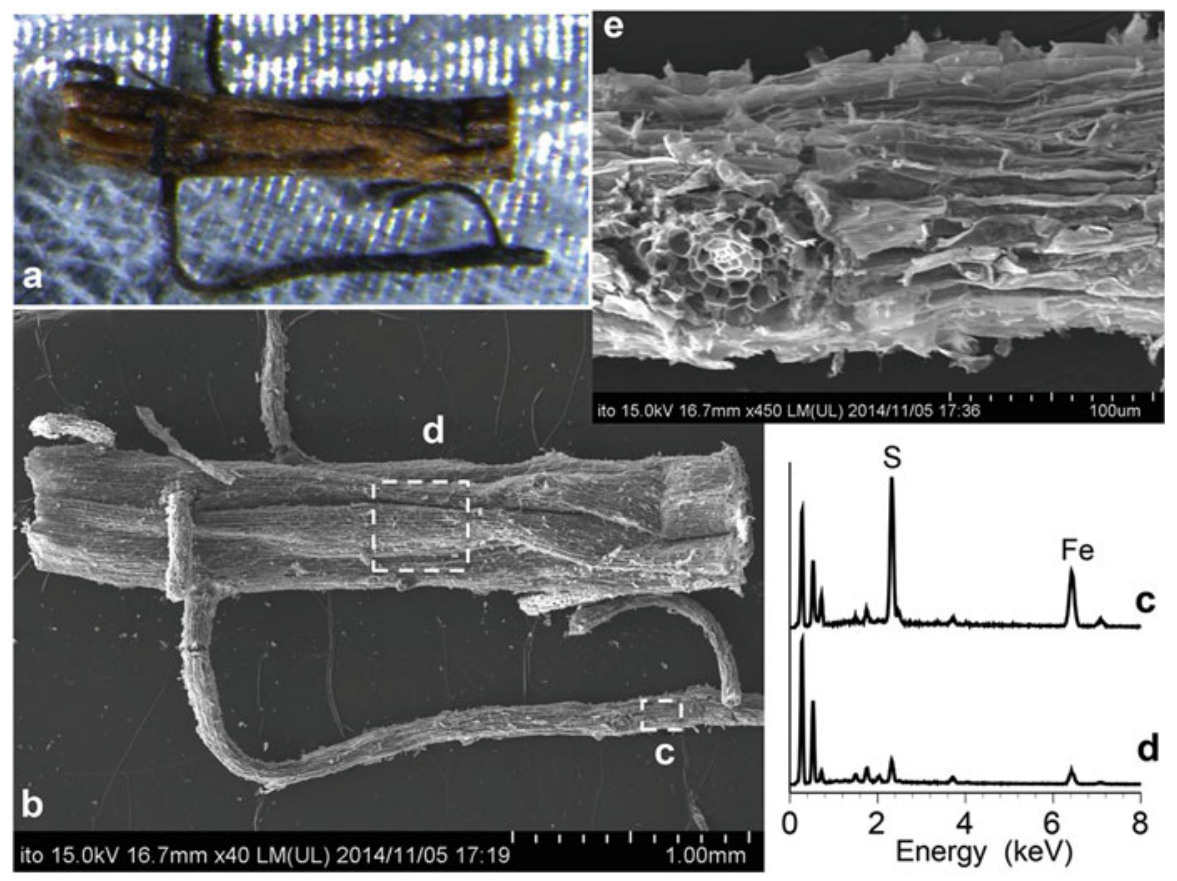

Fig. 5.25 Analyses of darkened rice root piece with gypsum application. (a) Optical photograph of rice root piece separated from the soil section shown in Fig. 5.24c, (b) SEM image of the rice root piece in (a), (c and d) EDX spectra for dashed areas (c) and (d) of the SEM image in (b), (e) magnified SEM image of dashed area (c) shown in (b)

Figures 5.26 and 5.27 show framboidal pyrite separated from the 2011 muddy tsunami deposit in Miyagi Prefecture, Japan (also see Sect. 6.2). At least at four sampling sites, muddy tsunami deposits with total $\mathrm{S}$ content between 8 and $23 \mathrm{~g} \mathrm{~kg}^{-1}$ contained framboidal pyrite, which is most commonly found in soils and sediments (Fanning et al. 2002). Figure 5.26a shows a SEM image of the framboidal pyrite. As shown in the EDX spectrum (Fig. 5.26b) and powder XRD pattern (Fig. 5.26c), and also in the element maps of S (Fig. 5.26d) and Fe (Fig. 5.26e), spherical or spheroidal crystal aggregates contain $\mathrm{S}$ and Fe as major elements; in addition, the powder XRD pattern includes a set of diffraction peaks from pyrite. Some of the crystal aggregates are partly broken. The pyrite samples shown in Figs. 5.26a and 5.27a were prepared after treatment by hot $\mathrm{KOH}$ digestion and separation of heavy mineral fractions (Valentyne 1963).

The crystal aggregates of pyrites are grayish gold or gold in color, and spherical or spheroidal in shape (Fig. 5.27a). Magnification of one of the crystal aggregates (Fig. 5.27b) shows that it consists of different crystal forms, such as octahedral (Fig. 5.27c) and polyhedral or sub-rounded (Fig. 5.27d) types. 

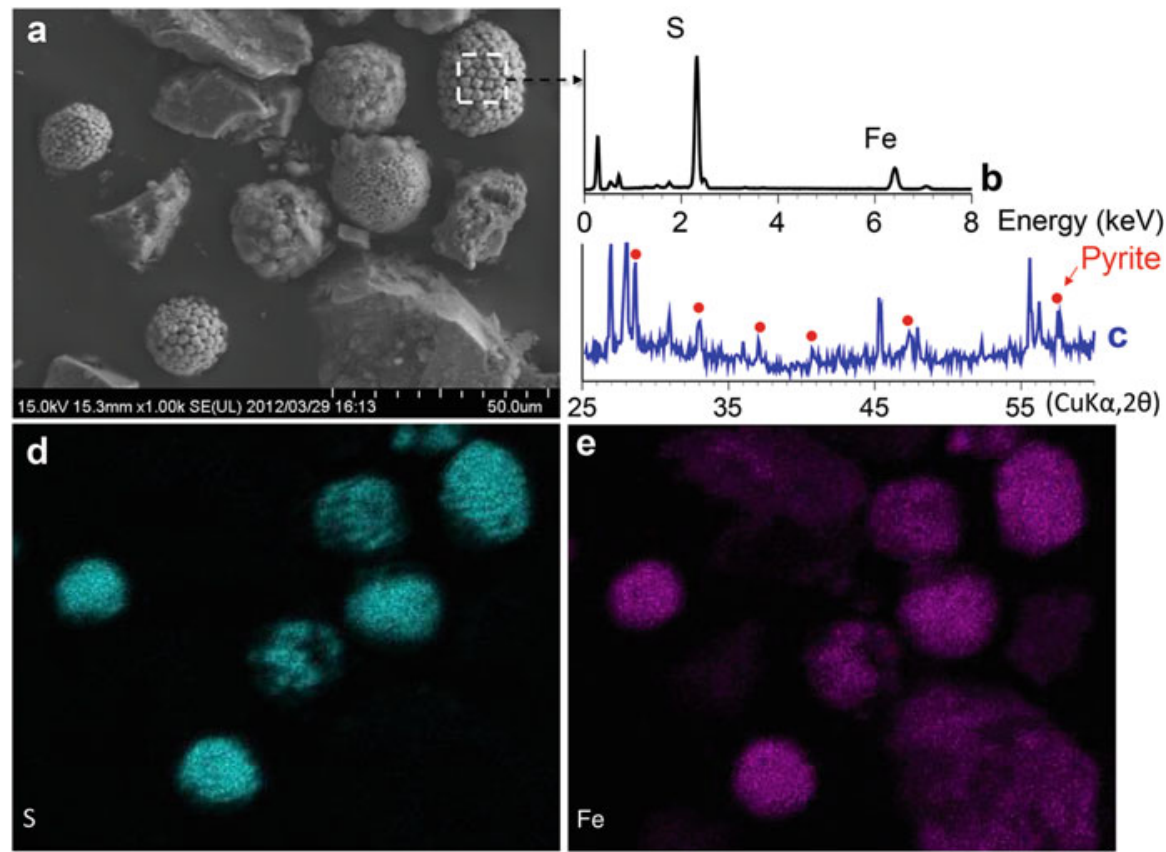

Fig. 5.26 Detection of framboidal pyrite. (a) SEM image including framboidal pyrite particles, (b) EDX spectrum of a framboidal pyrite particle, (c) XRD pattern including diffraction peaks from pyrite (red filled circles), (d and e) element maps for $\mathrm{S}$ and $\mathrm{Fe}$, respectively

The presence of pyrite or sulfidic materials can be evaluated by $\mathrm{pH}$ measurement after $\mathrm{H}_{2} \mathrm{O}_{2}$ treatment or incubation of soil samples at field capacity for 8 weeks. If the $\mathrm{pH}$ after this treatment is lower than 3 or 3.5, the soil contains a significant amount of sulfidic materials. Sulfidic soils are converted to strongly acid soils after oxidation (Soil Survey Staff 1999).

\subsubsection{Jarosite}

Jarosite is a sulfate mineral $\left[\mathrm{KFe}_{3}\left(\mathrm{SO}_{4}\right)_{2}(\mathrm{OH})_{6}\right]$ formed by oxidation of pyrite. A Na-substituted type of jarosite, natrojarosite $\left[\mathrm{NaFe}_{3}\left(\mathrm{SO}_{4}\right)_{2}(\mathrm{OH})_{6}\right]$, also exists. They are both stable under acidic conditions. One of the characteristics of acid sulfate soil (Fanning and Burch 2000) is significant amounts of jarosite or natrojarosite. Acid sulfate soils are distributed in coastal lowlands, which are affected by sea-level rise and fall. Chemical problems of acid sulfate soil are low $\mathrm{pH}$, lack of basic cations, excessive toxic Al, and high phosphate fixation. Soil amendments, such as liming 

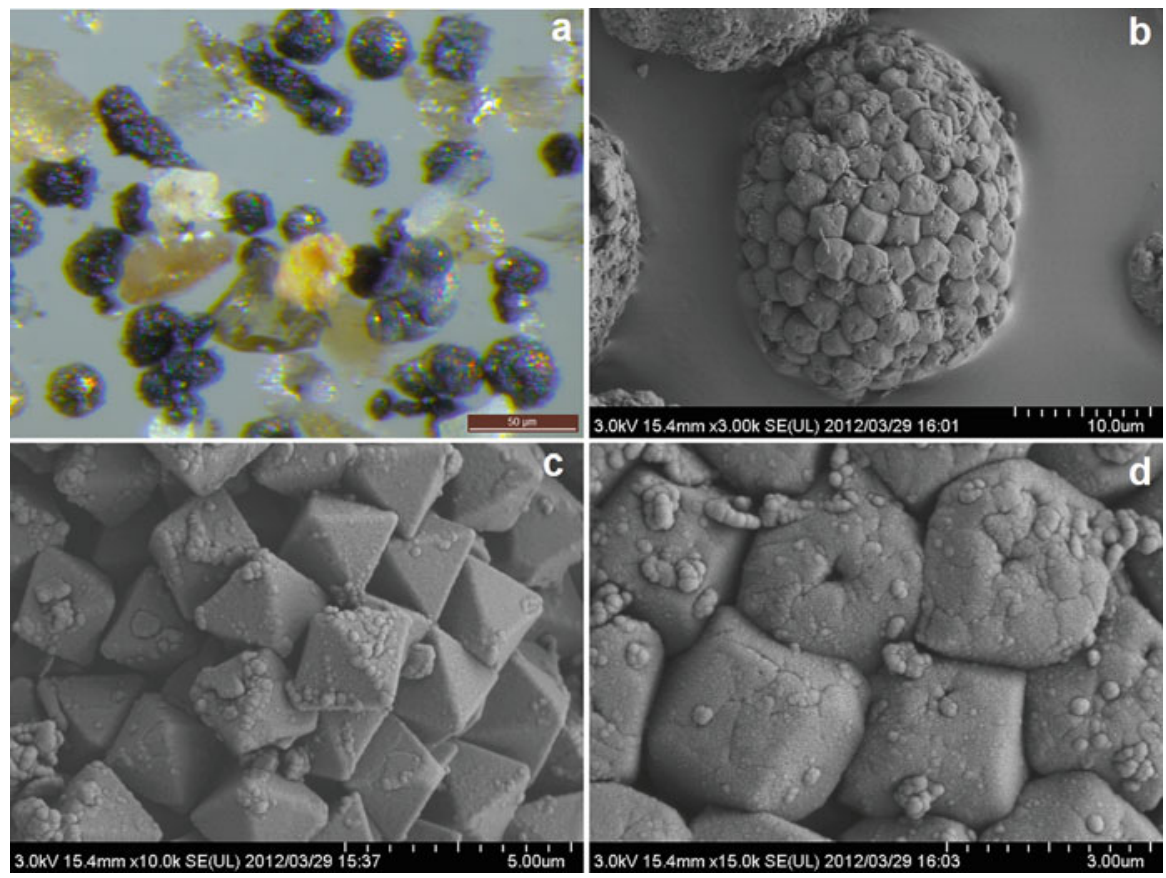

Fig. 5.27 Morphological properties of framboidal pyrite. (a) optical micrograph of framboidal pyrite particles, (b) magnified SEM image of a framboidal pyrite particle, (c) octahedral-type particles in framboidal pyrite, (d) polyhedral or rounded particles in framboidal pyrite

and application of other necessary fertilizers, are important in order to use these soils for agricultural production.

Figure 5.28 shows an example of natrojarosite. The sample field is presently used for sugarcane production (Fig. 5.28a). In the soil profile, the yellow patches at a depth of approximately $60 \mathrm{~cm}$ from the soil surface (Fig. 5.28b) are natrojarosite. The SEM image (Fig. 5.28c) shows pseudocubic crystal forms, and the EDX spectrum (Fig. 5.28d) obtained from the dashed square area (Fig. 5.28c) shows significant peaks for $\mathrm{Na}, \mathrm{S}$, and Fe. The powder XRD pattern (Fig. 5.28e) is similar to the reference pattern of natrojarosite (Fig. 5.28f).

Further readings for submerged soils and wetland soils are Kirk (2004), and Vepraskas and Craft (2016). 


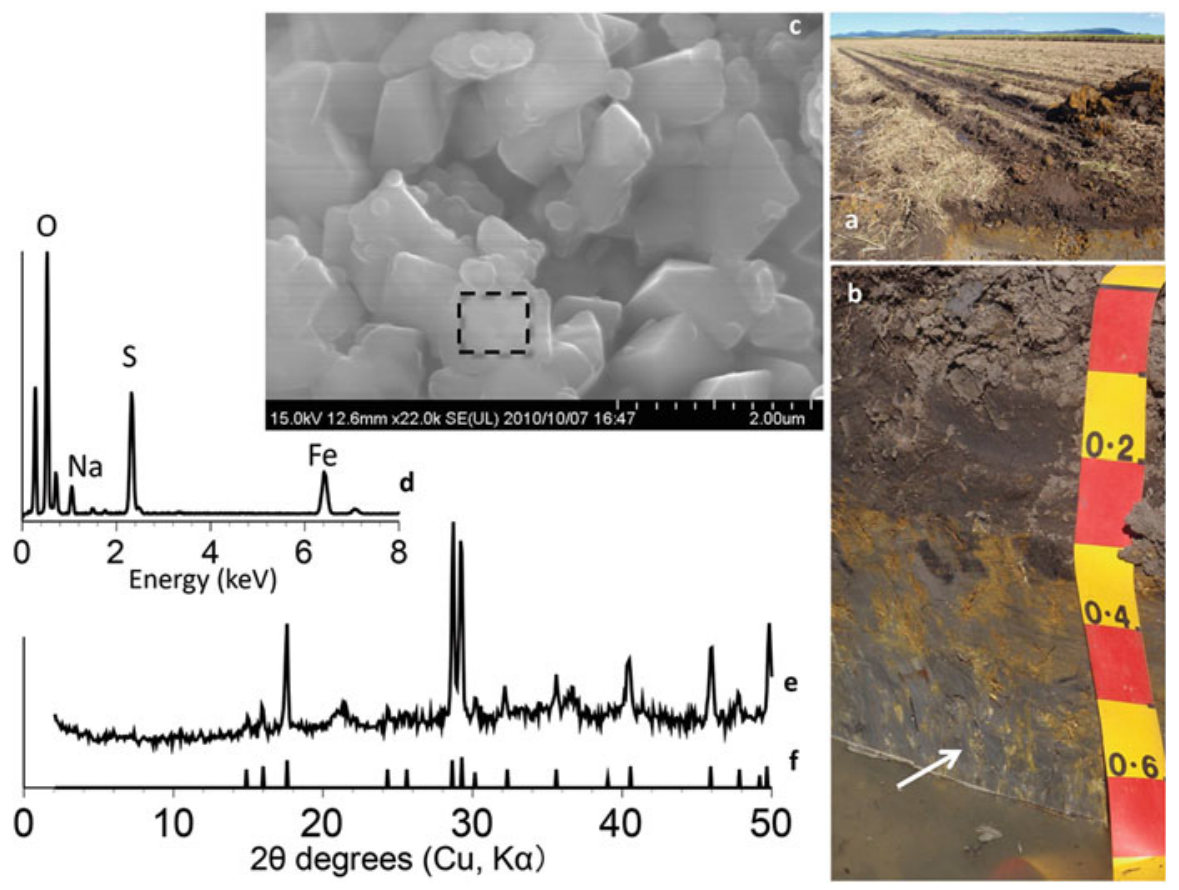

Fig. 5.28 An example of natrojarosite occurrence. (a) Landscape of soil containing sulfidic materials in the lower horizon, (b) soil profile containing natrojarosite (white arrow), (c) SEM image of natrojarosite, (d) EDX spectrum for the dashed area identified in (c), (e) XRD pattern of natrojarosite, (f) reference XRD pattern of natrojarosite (Brindley and Brown 1980)

\section{References}

Ando T, Yoshida S, Nishiyama I (1983) Nature of oxidizing power of rice plants. Plant Soil 72:51-57

Brindley GW, Brown G (1980) Crystal structures of clay minerals and their X-ray indentification, Mineralogical society monograph no.5. Mineralogical Society, London

Childs CW, Matsue N, Yoshinaga N (1991) Ferrihydrite in volcanic ash soils of Japan. Soil Sci Plant Nutr 37:299-311

Fanning DS, Burch SN (2000) Coastal acid sulfate soils, Reclamation of drastically disturbed lands, agronomy monograph, vol 41. American Society of Agronomy, Madison, pp 921-937

Fanning DS, Rabenhorst MC, Burch SN, Islam KR, Tangren SA (2002) Sulfides and sulfate. In: Dixon JB, Schulze DG (Co-eds) Soil mineralogy with environmental applications, Soil Science Society of America, Inc. Madison, pp 229-260

Fonseca EC, da Silva EF (1998) Application of selective extraction techniques in metal-bearing phases identification: a South European case study. J Geochem Explor 61:203-212

Fu Y-Q, Yang X-J, Ye Z-H (2016) Identification, separation and component analysis of reddish brown and non-reddish brown iron plaque on rice (Oryza sativa) root surface. Plant Soil 402:277-290

Garnd S, Lavkulich LM (1980) The oxidation mechanism of vivianite as studies by Moessbauer spectroscopy. Am Mineral 65:361-366 
Global Rice Science Partnership (2013) Rice almanac, 4th edn. Los Banos (Philippines), International Rice Research Institute

Glossary of Soil Science Committee (2008) Glossary of soil science terms. Soil Science Society of America, Inc, Madison

Hansel CM, Fendorf S, Sutton S (2001) Characterization of Fe plaque and associated metals on the roots of mine-waste impacted aquatic plants. Environ Sci Technol 35:3863-3868

Heiberg L, Koch CB, Kjaergaard C, Jensen HS, Hansen HCB (2012) Vivianite precipitation and phosphate sorption following iron reduction in anoxic soils. J Environ Qual 40:938-949

Hurt GW, Whited PM, Pringle RF (eds) (1996) Field indentification of hydric soils in the United States. US Department of Agriculture, Natural Resources Conservation Service, Fort Worth

Ito $\mathrm{J}$ (1975) Concretion of ferrous phosphate $\left(\mathrm{Fe}_{3}\left(\mathrm{PO}_{4}\right)_{2} .8 \mathrm{H}_{2} \mathrm{O}\right)$ appears in grey horizon of paddy soils. Bull Hokuriku Natl Agric Exp Stn 18:119-14 (In Japanese, with English abstract.)

IUSS Working Group WRB (2015) World reference base for soil resources 2014. International soil classification system for naming soils and creating lengends for soil maps, update 2015, World soil resources reports no.106. FAO, Rome

Kahn N, Seshadri B, Bolan N, Saint CP, Kirkham MB, Chowdhury S, Yamaguchi N, Lee DY, Li G, Kunhikrishnan A, Qi F, Karunanithi R, Qiu R, Zhu Y-G, Syu CH (2016) Root iron plaque on wetland plants as a dynamic pool of nutrients and contaminants. Adv Agron 138:1-96

Kawai M, Samarajeewa PK, Barrero RA, Nshiguchi M, Uchiymiya H (1998) Cellular dissection of the degradation pattern of cortical cell death during aerenchyma formation of rice roots. Planta 204:277-287

Kirk G (2004) The biogeochemistry of submerged soils. John Wiley \& Sons Ltd., Chichester 291p

Kojima M (1971) Micro-analysis of rusty mottlings in paddy soils. J Sci Soil Manure, Jpn 42:69-73

Komiyama T, Niizuma S, Fujisawa E, Morikuni (2013) Phosphorus compounds and their solubility in swine manure compost. Soil Sci Plant Nutr 59:419-426

Kondo M, Aguilar A, Abe J, Morita S (2000) Anatomy of nodal roots in tropical upland and lowland rice varieties. Plant Prod Sci 3:437-445

Kusunoki A, Nanzyo M, Kanno H, Takahashi T (2015) Effect of water management on the vivianite content of paddy-rice roots. Soil Sci Plant Nutr 61:910-916

Kyuma (2004) Paddy soil science. Kyoto University Press, Kyoto

Kyuma K, Mitsuchi M, Moormann FR (1988) Man-induced soil wetness: the "anthraquic" soil moisture regime. In: Kinloch DI, Shoji S, Beinroth FH, Eswaran H (eds) Proceedings of the ninth international soil classification workshop, Japan, 20 July to 1 August, 1987. Publ. by Japanese Committee for the 9th inernational soil classification workshop, for the soil management support service, Washinton DC, USA, pp 138-146

Lehr JR, Brown EH, Frazier AW, Smith JP, Thrasher RD (1967) Crystallographic properties of fertilizer compounds, Chemical Engineering Bull. 6. Tennessee Valley Authority, Knoxville

Lindsay WL (1979) Chemical equilibria in Soils. John Wiley \& Sons, New York, pp 163-209

Nanzyo M, Kanno H, Obara S (2004) Effect of reducing conditions on P sorption of soils. Soil Sci Plant Nutr 50:1028-1028

Nanzyo M, Yaginuma H, Sasaki K, Ito K, Aikawa Y, Kanno H, Takahashi T (2010) Identification of vivianite formed on the root of paddy rice grown in pots. Soil Sci Plant Nutr 56:376-381

Nanzyo M, Onodera H, Hasegawa E, Ito K, Kanno H (2013) Formation and dissolution of vivianite in paddy field soil. Soil Sci Soc Am J 77:1452-1459

Ponnamperuma FN (1972) The chemistry of submerged soils. Adv Agron 24:29-96

Rothe M, Kleeberg A, Hupfer M (2016) The occurrence, identification and environmental relevance of vivianite in waterlogged soils and aquatic sediments. Earth-Sci Rev 158:51-64

Sadana US, Claassen N (1996) A simple method to study the oxidizing power of rice roots under submerged soil conditions. Z Pflanzenahr Bodenk 159:643-646

Sadiq M, Lindsay WL (1979) Selection of standard free energies of formation for use in soil chemistry. Tech Bull 134, Colorado State Univ Expt Stn

Saito M, Kawaguchi K (1971a) Flocculating tendency of paddy soils (Part 1) periodical changes of physical properties of paddy soils under flooded conditions. J Sci Soil Manure, Jpn 42:1-6

Saito M, Kawaguchi K (1971b) Flocculating tendency of paddy soils (Part 3) structure of poorly drained paddy soils. J Sci Soil Manure, Jpn 42:61-64 
Schwertmann U (1973) Use of oxalate for Fe extractions from soils. Can J Soil Sci 53:244-246

Shiga H (1973) Effect of phosphorus fertility of soils and phosphate application on rice culture in cool region. Part 1. Measurement of phosphorus supplying ability of paddy soils. Res Bull Hokkaido Natl Agric Exp Stn 105:31-49 (In Japanese, with English abstract.)

Shiga H, Yamaguchi Y (1976) Effect of phosphorus fertility of soil and phosphate application on rice culture in cool region Part 3. On the relations with applied nitrogen and with variance of climate in continuous years. Res Bull Hokkaido Natl Agric Exp Stn 116:139-155 (In Japanese, with English abstract.)

Soil Survey Staff (1999) Soil taxonomy, a basic system of soil classification of making and interpreting soils surveys, USDA-NRCS, agriculture handbook no. 436, U.S. Government Printing Office, Washington, DC

Stumm W, Morgan JJ (1996) Oxydation and reduction; equilibria and microbial mediation. In: Aquatic chemistry, chemical equilibria and rates in natural waters, A Wiley-Interscience series of texts and monograph. Wiley Interscience, New York, pp 425-515

Togami K, Miura K, Ito K, Kanno H, Takahashi T, Nanzyo M (2017) Elemental affinity for siderite found in a Japanese paddy subsoil. Soil Sci Plant Nutr 63:101-109

Trolldenier G (1977) Mineral nutrition and reduction processes in the rhizosphere of rice. Plant Soil 47:193-202

Valentyne JR (1963) Isolation of pyrite spherules from recent sediments. Limnol Oceanogr 8:16-30

Vepraskas MJ (1992) Redoximorphic featrures for identifying aquic conditions. North Carolina State University Technical Bulletin 301, Raleigh, North Carolina, USA

Vepraskas MJ, Craft CB (2016) Wetland soils - genesis, hydrology, landscapes, and classification, 2nd edn. CRC Press, Taylor \& Francis group, Boca Raton-London-New York

Wada H, Neue H-U (1988) Chemistry and biochemistry of paddy soils. In: Kinloch DI, Shoji S, Beinroth FH, Eswaran H (eds) Proceedings of the ninth international soil classification workshop, Japan, 20 July to 1 August, 1987. Publ. by Japanese Committee for the 9th inernational soil classification workshop, for the soil management support service, Washinton DC, USA, pp $115-12$

Wada H, Miyashita K, Takai Y (1977) Studies on the decomposition process of plant residue in the paddy field. J Sci Soil Manure, Jpn 48:166-170 (in Japanese)

Walpersdorf E, Koch CB, Heiberg L, O'Connell DW, Kjaergaard C, Hansen HCB (2013) Does vivianite control phosphate solubility in anoxic meadow soils ? Geoderma 65:193-194

Yagi (1997) Methane emissions form paddy fields. Bull Natl Inst Agro-Environ 14:96-210

Yoshida H, Matsuoka K (2004) Occurrence of 'Takashikozo' from Takashihara area, AichiPrefecture. Bull Nagoya Univ Museum 20:25-34 (In Japanese with English abstract)

Zelibor JL Jr, Senftle FE, Reingardt JL (1988) A proposed mechanism for the formation of spherical vivianite crystal aggregates in sediment. Sediment Geol 59:125-142

Open Access This chapter is licensed under the terms of the Creative Commons Attribution 4.0 International License (http://creativecommons.org/licenses/by/4.0/), which permits use, sharing, adaptation, distribution and reproduction in any medium or format, as long as you give appropriate credit to the original author(s) and the source, provide a link to the Creative Commons license and indicate if changes were made.

The images or other third party material in this chapter are included in the chapter's Creative Commons license, unless indicated otherwise in a credit line to the material. If material is not included in the chapter's Creative Commons license and your intended use is not permitted by statutory regulation or exceeds the permitted use, you will need to obtain permission directly from the copyright holder. 